\title{
Towards Systematic Sustainable Business Model Innovation: What Can We Learn from Business Model Innovation
}

\author{
Vinicius Minatogawa ${ }^{1, *(\mathbb{D})}$, Matheus Franco ${ }^{2}\left(\mathbb{D}\right.$, Izabela Simon Rampasso ${ }^{3}{ }^{(}$, Maria Holgado ${ }^{4}{ }^{\circ}$, Diego Garrido ${ }^{5}$, \\ Hernan Pinto ${ }^{1}$ and Ruy Quadros ${ }^{2}$
}

1 Escuela de Ingeniería de Construcción y Transporte, Pontificia Universidad Católica de Valparaíso, Valparaíso 2340000, Chile; hernan.pinto@pucv.cl

2 Geosciences Institute, Department of Science and Technology Policy, University of Campinas, Campinas 13083-855, SP, Brazil; matheusfranco400@gmail.com (M.F.); ruy@unicamp.br (R.Q.)

3 Departamento de Ingeniería Industrial, Universidad Católica del Norte, Antofagasta 1270709, Chile; izabela.rampasso@ucn.cl

4 Department of Management, University of Sussex, Brighton BN1 9RH, UK; m.holgado@sussex.ac.uk

5 School of Industrial Engineering, Pontificia Universidad Católica de Valparaíso, Valparaíso 2362807, Chile; diego.garrido.mz@gmail.com

* Correspondence: vinicius.minatogawa@pucv.cl

Citation: Minatogawa, V.; Franco, M.; Rampasso, I.S.; Holgado, M.; Garrido, D.; Pinto, H.; Quadros, R. Towards Systematic Sustainable Business Model Innovation: What Can We Learn from Business Model Innovation. Sustainability 2022, 14, 2939. https://doi.org/10.3390/ su14052939

Academic Editors:

Sooksan Kantabutra and

Marc A. Rosen

Received: 1 November 2021

Accepted: 3 February 2022

Published: 3 March 2022

Publisher's Note: MDPI stays neutral with regard to jurisdictional claims in published maps and institutional affiliations.

Copyright: (c) 2022 by the authors. Licensee MDPI, Basel, Switzerland. This article is an open access article distributed under the terms and conditions of the Creative Commons Attribution (CC BY) license (https:// creativecommons.org/licenses/by/ $4.0 /)$.

\begin{abstract}
This research aims to understand how sustainable business model innovation (SBMI) can learn from business model innovation. For this, first, we conducted a bibliometric analysis to evaluate the relationships between business model innovation and SBMI literature. After this, we performed a systematic literature review to create a comprehensive framework for managing SBMI. The bibliometric analysis showed that the SBMI stream grew quickly and significantly in recent years, evolving into a separated new research stream, which does not leverage recent business model innovation advancements. Through the performed analyses, we were able to discuss critical gaps in the SBMI literature and shed light on possible pathways to solve these gaps through lessons learned from business model innovation. We depicted five critical gaps for managing SBMI; (1) the need to understand the sustainable business model as a wicked problem, in which SBMI leads to "better than before" solutions calling for systematic SBMI, (2) the poor definition of distinctive dimensions of dynamic capabilities for SBMI, (3) the lack of studies exploring the role of open innovation for improving the SBMI process, (4) the lack of tools supporting SBMI implementation and (5) the need to explore game-changing, competitive advantages of SBMI. The findings of this study contribute to guiding future research on SBMI, which can be a basis for further efforts towards sustainable development.
\end{abstract}

Keywords: sustainable business model innovation; business model innovation; business model innovation for sustainability; bibliometric analysis; systematic literature review; dynamic capabilities; organizational design; supply networks; experimentation

\section{Introduction}

The 26th UN Climate Change conference in Glasgow, Scotland, reinforced the need for companies' commitment to sustainable development [1,2]. In this context, the conference highlighted the need to transform different industries' business models for sustainability $[3,4]$. A business model for sustainability, also known as a sustainable business model (SBM), represents how a company creates, delivers, and captures value while generating positive effects and/or reducing negative impacts on the environment and society [5].

There are some exciting examples of startups developing new SBMs. Bureo, a Chilean startup [6], creates value from its discarded fishing nets' palletizing process. From this material, the startup manufactures and markets skateboards, delivering and capturing value. Their business model reduces negative environmental effects by preventing harmful materials from contaminating the ocean. At the same time, Bureo generates a positive social impact as the model supports local fishing communities through financial incentives [7]. 
The literature characterizes the ideation and development of new SBMs as sustainable business model innovation (SBMI). SBMI refers to the business model transformation/creation process that balances economic, social, and environmental aspects, mitigating possible tensions between these aspects [8]. However, such a type of innovation is limitedly adopted by large companies [9]. As SBMI scholars affirm (despite compelling punctual cases, i.e., [10]), companies' adoption of SBMI has been, so far, disappointing [11]. This, therefore, deserves further investigation.

Such shortcomings have been partly related to the lack of dynamic capabilities (for clarification and definition, refer to Teece [12,13]) for SBMI $[9,14]$, a diagnostic that business model innovation (BMI) scholars share as a plausible explanation for the poor systematization of BMI. Nowadays, the BMI research field focuses on how to measure and build [15] such capabilities for BMI, enabling companies to (systematically) implement BMI [16]. This is reasonable, considering that dynamic capabilities enable companies to systematically create new and modify their existing operational routines [17], renewing their key competencies according to the context changes [18]. Additional gaps are found between SBMI design and its implementation in the literature $[19,20]$. Few studies help to offer an integrative view of the tools, their relation to SBMI processes, and how to implement SBMI [21]. BMI literature again appears at an advanced stage compared to SBMI. Several studies present tools (mainly regarding design tools) [22,23] and processes that help understand every BMI phase and the associated activities [24,25].

Due to its faster development in the different areas exposed above (which are claimed gaps for SBMI), BMI literature has significant potential to aid the development of SBMI, through a "learning by analogy" approach. However, there is no account of whether and how the BMI literature has influenced SBMI literature, and no comparative works have been found. This represents a knowledge gap and leads to the definition of our research goals. The first goal of this study is exploring the relationship between BMI and SBMI literatures in an organized manner. Moreover, it is critical for companies aiming to become sustainable to follow a systematic approach to managing SBMI. The search for sustainability is a continuous process, not a goal [26]. Thus, the search for SBMI systematization is coherent, especially considering that new SBMs are too important to result from randomness. Nevertheless, the literature highlights gaps associated with SBMI dynamic capabilities, design, and implementation. Thus, we establish the second research goal, which is to answer the question of what antecedents, capabilities, tools, and processes should be part of a systematic approach to SBMI.

We first executed a bibliometric analysis to illustrate overlaps and the relationships between BMI and SBMI literature. We used a comparative approach that enables learning by analogy and reveals opportunities and gaps to deal with SBMI challenges. While novel for SBMI, the BMI research has also taken lessons from adjacent disciplines, for example, from product innovation [27]. Our bibliometric analysis findings show that the SBMI stream grew quickly and significantly in recent years, evolving into a separated new research stream, sharing only seminal works from BMI. Hence, showing that SBMI has diverged from BMI, and is not leveraging recent BMI advancements. Additionally, while SBMI's recent publications move towards experimentation, BMI passed this stage between 2010 and 2015, and today focuses more on dynamic capabilities, which is not yet a trend for SBMI.

Second, we conducted a systematic literature review (SLR) to uncover key attributes for SBMI. Our SLR findings show predominant SBMI research streams regarding (1) sustainabilityoriented BMI, (2) SBMI firm-level antecedents, and (3) SBMI design tools and processes. Sustainability-oriented BMI focuses on exploring environmental, economic, and social value, but does not necessarily present it in an integrated manner, not accounting for the need to understand SBM as a wicked problem, in which SBMI leads to "better than before" solutions, which calls for systematic SBMI, rather than SBM as a solid design output. Moreover, unlike mainstream BMI, they do not focus on showing competitive advantages and game-changing aspects. SBMI antecedents indicate organizational design as the critical managerial change lever, which shapes dynamic capabilities of sensing, 
seizing, and transforming needed to execute the SBMI process. It aligns with the most recent BMI advancement; however, studies only mention and do not explore further the potential dynamic capabilities for SBMI, and there is a clear lack of studies exploring the role of open innovation for SBMI. The final research stream is the most explored and provides several tools, methods, activities, and practices while defining the SBMI process. However, these are much more related to identifying opportunities and designing SBMs than transforming and escalating.

This study is structured as follows. The following section presents the theoretical background, exploring underpinning concepts and clarifying our research background better. In Section 3, we present the adopted method. We show our core findings in Section 4. We then discuss the findings and main research gaps for SBMI management in Section 5. Finally, we conclude this study in Section 6.

\section{Theoretical Background}

\subsection{Sustainable Companies and Sustainable Business Models}

The literature points out several aspects relating to companies and sustainability. A sustainable company creates benefits for all stakeholders while acting in the preservation of the environment and contributing to people's lives [28]. Based on this definition and considering the abovementioned SBM definition, we can affirm that sustainable companies need an SBM. For example, it is not enough for a sustainable company to deliver a new ecofriendly product (as a value to its customers). If its value creation processes, i.e., how the company develops and distributes this product, harm the environment, how can it be considered sustainable? If the value capture, i.e., how the company obtains returns on the delivered product, causes negative social impacts, such as encouraging excessive consumerism [29], how can it be considered sustainable?

Thus, a company's sustainability does not mean the condition of lasting over time without considering its surrounding context and the ecosystem in which it operates. Companies and their business model are part of a system, and changes in one dimension of sustainability will necessarily impact others [30]. For this reason, sustainable enterprises are often related to the concept of sustainable development [31], conceptualized as: "development that meets the needs of the present without compromising the ability of future generations to meet their own needs" [32]. Sustainable development, therefore, usually involves tensions between social, ecological, and economic objectives [33]. These dimensions characterize the framework called the triple bottom line.

Thus, sustainable development is a process of change in which the exploitation of resources, decisions on investments, the orientation of technological development, and institutional transformations must be in harmony to enhance human needs and aspirations in the present and future [32]. Meeting the triple bottom line is a process of change in search of balance, so is part of SBMI processes.

When companies fail in this process of change, their activities can generate negative impacts on society and the environment [34]. The hard truth is that many companies have failed. From responding to the effects of climate change [35] up to the incorporation of circular economy principles into their strategies [36], integrating sustainability has not been a trivial task. According to Molina-Castillo et al. [37], the logical foundation for sustainable companies lies in the value proposition and the capability for innovation. However, it is necessary to understand how the company's value proposition is being created, delivered, and captured for the dimensions of sustainability.

Natura, a Brazilian cosmetics company, is an excellent example of how to develop innovative SBM. The company delivers high-quality cosmetics as a value to its consumers, competing with other significant players such as L'Oreal, $P \& G$, and Unilever. However, its value creation process differs by promoting Amazonia's Forest preservation while also contributing to the local families' development. For example, in some of its products, the company uses uccuba tree seeds. Local communities used to cut down these trees to produce wooden goods. These communities earn more advantageous revenues now, supplying 
uccuba seeds to Natura and avoiding millions of miles of deforestation. In addition, in its value capture process, i.e., in the sale of cosmetics, Natura reverts part of its revenues to the communities to promote ecosystem preservation projects. For example, local wildlife conservation projects [38].

Natura's SBM covers all dimensions of the triple bottom line, characterizing it as a fully sustainable company. Full sustainability entices total accomplishment of economic, social, and environmental value creation [39]. If any dimension is not fully addressed, then it is not fully sustainable. It is possible to be economically feasible while also protecting the environment. However, without social value creation, it is still not fully sustainable. This combination is called ecological, given the potential protection of the Earth's longterm health combined with economic feasibility, a must in a capitalist society $[40,41]$. Considering the example of Natura, it is not surprising that SBMI has been observed as a lever for changing a system to achieve sustainability [41].

\subsection{What Can We Learn from Other SBM and SBMI Reviews?}

The power of BMI to transform from enterprise systems to the logic of entire industries is well described in the literature. The growing academic interest in the subject has been notorious in the last 20 years [42]. Today, besides better conceptual understanding, it is also possible to find applied studies and branches that explore BMI for specific functions. Since the mid-2010s, the sustainability branch has attracted the interest of researchers. The graph shown in Figure 1 reveals search results for the terms "Business Model Innovation", "Sustainable Business Model", and "Sustainable Business Model Innovation" using the Web of Science database. For better visualization, we used a logarithmic scale (base 2).

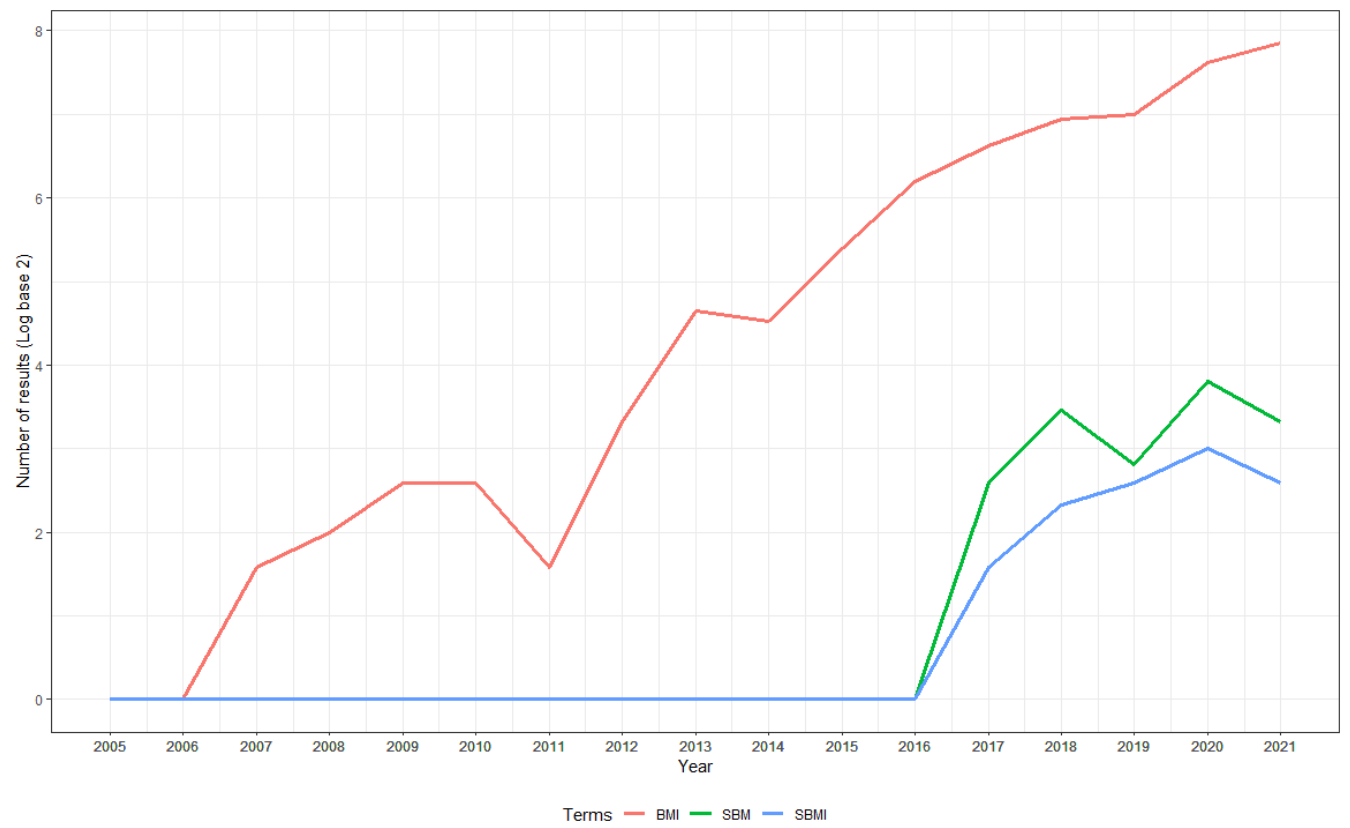

Figure 1. Web of Science results for the terms "Business Model Innovation", "Sustainable Business Model" and "Sustainable Business Model Innovation.

The relationship between SBM and SBMI macroconstructs deserves specific attention. Foss and Saebi [42] evidence how the business model concept evolved long before the first studies on its innovations. That same logic does not seem so clear to SBM and SBMI. The literature seems to be developing the concept of SBM while seeking to explore innovations that make business models sustainable. To understand how these macroconstructs are developing, we analyze all the literature reviews found on both topics in the Web of Science. Table 1 compiles relevant information about these revisions. 
Table 1. Articles reviewing SBM and SBMI.

\begin{tabular}{|c|c|c|}
\hline Authors Reviewing SBM & Findings & Data Source and Samples \\
\hline Bocken et al. [40] & $\begin{array}{l}\text { - } \quad \text { Categorize SBM into archetypes } \\
\text { - } \quad \text { Develop eight archetypes }\end{array}$ & $\begin{array}{c}\text { Web of Knowledge, Scopus, EBSCO } \\
\text { Host, ProQuest, and SAGE Journals } \\
\text { n }=\text { not specified }\end{array}$ \\
\hline Nosratabadi et al. [43] & $\begin{array}{l}\text { - } \quad \text { Classify SBM into categories } \\
\text { - } \quad \text { Present } 14 \text { unique categories }\end{array}$ & $\begin{array}{l}\text { Web of Science and Scopus } \\
\qquad n=66\end{array}$ \\
\hline Goni et al. [44] & $\begin{array}{l}\text { - } \quad \text { Reveal main aspects an SBM needs to consider } \\
\text { - } \quad \text { Highlight nine aspects that SBM must possess }\end{array}$ & $\begin{array}{c}\text { Several scientific databases, including } \\
\text { Science Direct, Scopus, and } \\
\text { Google Scholar } \\
\mathrm{n}=\text { not specified }\end{array}$ \\
\hline Authors Reviewing SBMI & Findings & Data Source and Samples \\
\hline Barth et al. [45] & $\begin{array}{l}\text { - Propose a conceptual framework for SBMI in the } \\
\text { agri-food sector: } \\
\text { - Reveal four building blocks: value proposition, } \\
\text { value creation and delivery, value capture, and } \\
\text { value intention }\end{array}$ & $\begin{array}{c}\text { Web of Science, Scopus, ABI/Inform, } \\
\text { Emerald, Science Direct, Academic } \\
\text { Search, Springer-Link, Jstor, Sage, } \\
\text { and Agricola } \\
\text { n }=21\end{array}$ \\
\hline
\end{tabular}

- Provide a review of the key underlying concepts

$\begin{array}{ll}\text { Geissdoerfer et al. [19] } & \text { of BMI, SBM, and SBMI. } \\ \text { - Identify a research gap. } \\ \text { - Deduct research questions to address the gap. }\end{array}$
Web of Science and Scopus
$\mathrm{n}=$ not specified
- Propose SBMI components.

- Develop a framework that comprises three

Shakeel et al. [20] components: Value proposition, value creation and delivery, value capture
Scopus and Web of Science $\mathrm{n}=61$
Sinkovics et al. [46]
- Introduce an integrative framework of SBMI.

- Reveal SBMI antecedents, manifestations of SBMI, and SBMI outcomes.
Web of Science

$\mathrm{n}=57$ (umbrella review)

Reviews regarding SBM have a closer relationship to conceptual construction and the definition of its elements. Bocken et al. [40] categorize and develop SBM archetypes. Nosrabatadi et al. [43] present 14 categories of SBM, besides pointing to taxonomies regarding the theme. Goni et al. [44] reveal a framework with SBM key features, considering nine main aspects for this type of construct. These studies, however, were not oblivious to innovation, bringing contributions also to SBMI.

SBMI-specific reviews were also not limited to addressing innovation. Geissdoerfer et al. [19], for example, reviewed the main concepts of SBM and attempted to differentiate and relate "Business Models"; "Sustainable Business Models" and "Circular Business Models" before advancing in SBMI literature. Such analysis reinforces that the construction of these concepts is developing concomitantly.

Sinkovics et al. [46] introduce a comprehensive framework on SBMI. Authors adapted Barth et al. [45], Geissdoerfer et al. [19], and Nosratabadi et al. [43], among other studies, to develop an integrative framework. Thus, they present antecedents, dividing into micro, meso, and macro levels, manifestations, and results of SBMI.

However, all studies in Table 1 report the need for greater clarity on processes related to SBMI. Sinkovics et al. [46] highlight the need to identify the conditions that promote SBMI design and implementation. For Shakeel et al. [20], SBMI needs further studies that explore 
its implementation and experimentation in different contexts. Geissdoerfer et al. [19] question how organizations can transform BMs to SBMs in practice. The authors also specify that it would be essential to point out the phases, activities, and challenges of this process. Barth et al. [45] report the need to delve into the concept of "value intention", which relates to the mindset of decision-makers regarding attitudes to change and innovation.

All these issues converge to highlight the need for solutions to systematize SBMI. That is, solutions that enable managing processes, tools, antecedents, and resources for (continuous) new SBM creation or transformation. The importance of a systematic approach to SBMI so that the search for new SBMs becomes a capability and not an end in itself, allowing companies to become more sustainable by exploring new business models systematically. Interestingly, the BMI literature seems little explored in this regard. It is not clear if SBMI literature relies on BMI management knowledge. That is, does SBMI build on the most recent advancements of BMI research?

\subsection{Systematic Business Model Innovation}

The event known as the dot-com bubble was a milestone for business model studies [47]. The postcrisis brought the success of startups, and new business models stood out, displacing old ones. The interest of scholars and managers on this topic grew considerably, and BMI gained momentum [42]. Despite relevant theoretical contributions, it was discussed why most attempts to implement BMI was failing [48]. Given its importance, BMI should not be something random. Instead, companies needed to lead BMI activities through BMI processes, or, in other words, manage BMI [49].

The BMI field is still answering to this reality by moving from conceptualizing BMI towards systematic BMI, learning, for instance, from innovation management [27]. Thus, literature started to explore BMI antecedents, tools, and processes, in the efforts towards proposing a business creation engine-a never-ending approach to uncover and create new business models [15]. Hence, many novel BMI studies target such an organizational phenomenon and offer approaches regarding experimentation [50], ambidexterity [51], open innovation [52,53], dynamic capabilities [15], and organizational design [54].

It is important to note that systematic BMI is still in development. What we argue, however, is that its process is more advanced, and lessons can be learned and considered in further advancements of SBMI literature. Sustainability aspects will obviously bring further layers of complexity to systematization of the innovation process. While BMI focuses on the economic aspect, SBMI needs to balance social and environmental aspects. In this regard, it will be essential to understand how the SBMI literature presents this balance between the triple-bottom-line dimensions. That is, what types of sustainable-oriented BMI can be found in the literature?

In addition, sustainability should be understood as a continuous process, which varies according to needs and contexts, and not as a fixed goal $[55,56]$. Understanding sustainability systematically reinforces the need to move forward in search of a sustainable business creation engine. Thus, it seems pertinent to explore in the literature how companies are managing SBMI. That is, what antecedents, tools, and processes are related to SBMI?

\section{Method}

To develop our method, we combined bibliometric analysis and SLR. Through the bibliometric analysis, we intend to understand if SBMI and BMI research fields are evolving together (i.e., one seizes the other advancements), in parallel and separated (i.e., they both develop, but has few dialogs), or one substitutes the other (i.e., SBMI replaces BMI). Our objective is understanding whether SBMI builds on the most recent BMI advancements. With the SLR, the goal is to understand and organize the SBMI literature into an integrative framework for systematically conducting SBMI. The aim is to discover (1) what the types of sustainable-oriented BMI are, (2) what the antecedents are, and (3) what the tools and processes related to SBMI are. Combining such approaches minimizes findings' misinterpretation. Additionally, it enhances the value of the literature review $[57,58]$. 


\subsection{Bibliometric Analysis}

A bibliometric analysis allows a deep understanding of the relationship between articles, citations, co-citations, and keywords. Thus, results can provide relevant information about a research field through a reliable analysis of hundreds of articles. Finally, bibliometric results are usually visual-oriented, providing better comprehension for readers [58]. The first step of the bibliometric analysis was to collect the documents in the Web of Science and Scopus databases. To this end, we used the general query containing only the term "Business Model Innovation" in the title, abstract, or keywords. This decision was made considering it provides results for any string that combines something with business model innovation, i.e., "sustainable business model innovation", "Business model innovation for sustainability", "circular business model innovation", and so on. Hence, the search would provide us a clear vision of the whole BMI field and subfields for the bibliometric analysis, allowing us to investigate the relationship between SBMI and BMI literature.

We conducted the search in September 2021, and we found 1968 documents analyzed with VOSviewer ${ }^{\circledR}$. We highlight that before processing the content in the software, we grouped similar terms (e.g., sustainable business model + SBM) and removed words that did not present any conceptual contribution (e.g., chapter, issue, researcher, etc.). These adjustments were performed through Thesaurus, as recommended by van Eck and Waltman [59].

We performed bibliographic coupling analysis to relate BMI and SBMI. The aim was to generate visualizations of document and publication sources clusters. We defined the threshold of 15 citations for inclusion in the clustering. We also considered a minimum of 25 items per cluster. We determined the number of citations and the number of items per cluster based on similarity analysis between clusters.

\subsection{Systematic Literature Review}

SLR provides a thorough analysis clarifying contextual relationships, aiming to identify, specify, map, and evaluate the literature in a systematic, objective, and replicable way. Their results refer to a given knowledge field's state of the art [60]. In the following subsections, we present the steps conducted in this SLR [61,62]. We followed Denyer and Tranfield's [60] guidelines, which is an approach used in other studies [61,62].

\subsubsection{Step 1-Research Questions}

According to the mentioned guidelines, the first step is to formulate the research questions that will determine the scope of the analysis. Based on the context presented in the theoretical background, we define three guiding questions for the SLR: (1) How does the literature present the SBMI outcomes? (2) What firm-level antecedents can be associated with SBMI? Additionally, (3) what design tools and processes are associated with SBMI?

\subsubsection{Step 2-Search Procedures}

In the second step, we established the search procedures. As our research goal is to investigate the SBMI literature, and we used the following search query: "sustain* business model* innov" $^{*}$ OR "business model* innov* for sustain*" OR "sustain* oriented business model* innov*" OR "sustain*-oriented business model* innov*" OR "sustain* innov* of business model" ${ }^{* \prime}$ OR "sustain* innov* in business model" ${ }^{*}$ OR "business model* innov* toward* sustain ${ }^{* \prime \prime}$ ), in Scopus (title, abstract and/or keywords) and Web of Science (topic). The search was conducted on November 282021.

\subsubsection{Step 3-Selection and Evaluation}

In this step, we used the PRISMA flowchart [63] (Figure 2) to guide the selection and evaluation step. 


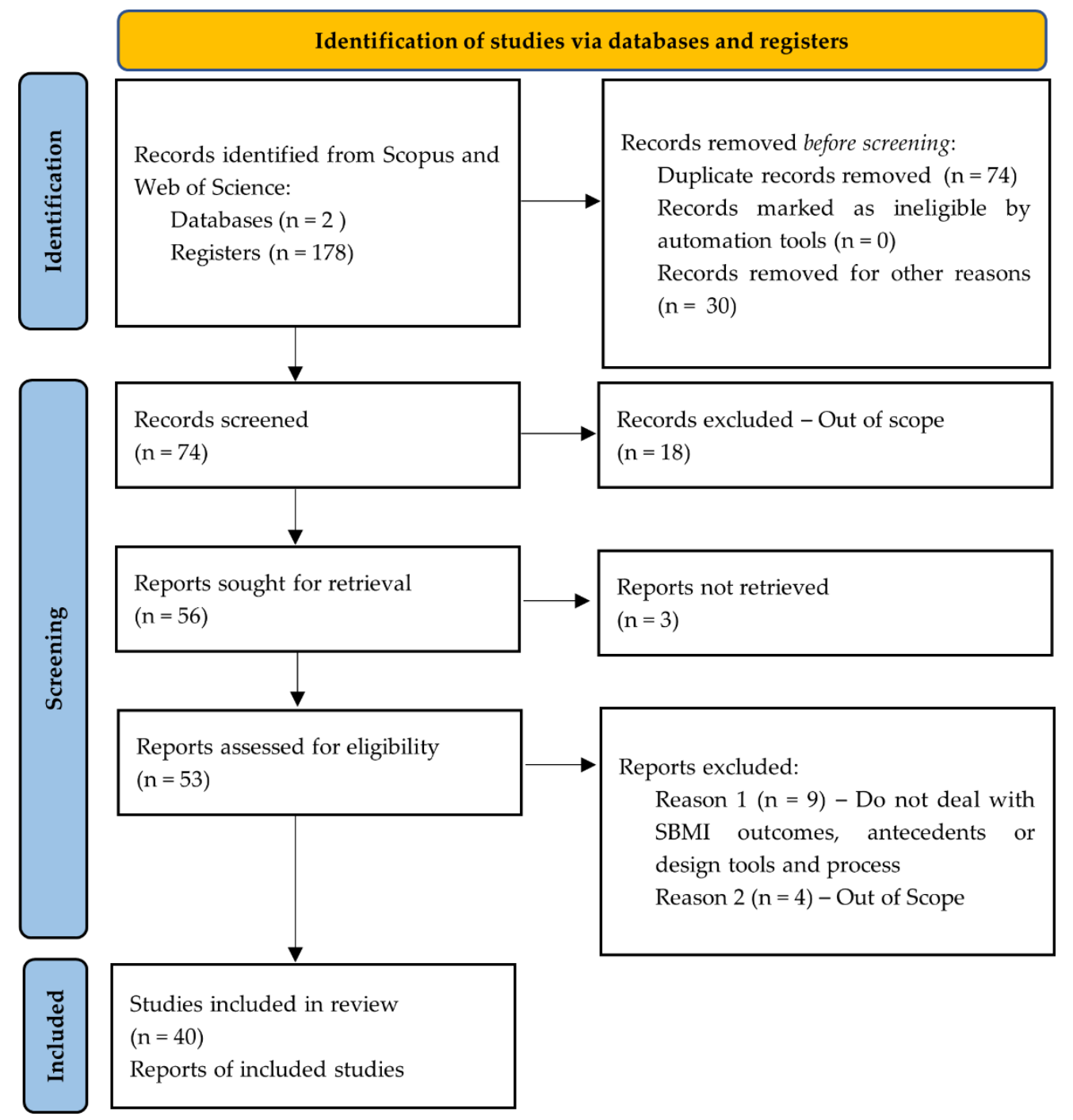

Figure 2. Flowchart of the data collection process adapted from the PRISMA recommendations.

\subsubsection{Step 4-Analysis and Synthesis}

In the fourth step, to perform the analysis and synthesis phase, we followed the recommendations of Elo and Kÿngas [64], which are described here to ensure the research reliability. At the beginning of this phase (organizing phase), the authors needed to define the approach to be used. The content analysis can be inductive or deductive. In this research, we used an inductive approach due to the lack of previous structures to be used in classification. We first analyzed the articles from the sample to develop an open coding of their content. We then created coding sheets through an analysis of texts' content. This analysis confirmed our proposition of major classification groups of SBMI types and outcomes, firm-level antecedents, and process and supporting tools, methods, activities, and practices. We then moved forward to create subcategories for each of the three major groups, further refining our codification.

The categorization matrix was developed using these coding sheets and the sample articles allocated in this matrix according to their classification. We allowed some publications in more than one category since some publications contribute to several categories. After the classification, it was necessary to conduct the abstraction of the content through an in-depth analysis of the sample publications to establish an overview of the current literature on SBMI. All classifications and results were qualitatively accessed and thoroughly discussed by the authors, involving synthesizing multiple opinions to enrich the quality of the result. 


\subsubsection{Step 5-Report and Conclusions}

The results present answers to the SLR questions. The discussion of the results, however, raised additional questions. Thus, we identify what we believe are critical gaps regarding SBMI management literature, critically accounting and comparing with recent advancements in the BMI literature.

\section{Results}

In this section, we show our systematic literature review results. We first draw on a bibliometric analysis of the business model innovation literature using VOSViewer@ to evaluate the SBMI field evolution and its connection to BMI research. In sequence, we present the in-depth bibliographic review, considering 40 SBMI research papers. We introduce the main research streams regarding the SBMI management concept.

\subsection{Bibliometric Analysis}

A comparative analysis with VOSviewer ${ }^{\circledR}$ shows a clear and significant separation between SBMI and BMI. From Figure 3, we notice a clear separation between the red cluster, which represents the SBMI authors around Bocken et al. [40], and the blue, green, and yellow clusters of BMI authors, such as Foss and Saebi [42], Sosna et al. [50], and Chesbrough [65]. We also notice that the yellow, green and blue clusters share many connections, are closer to each other, and are intertwined.

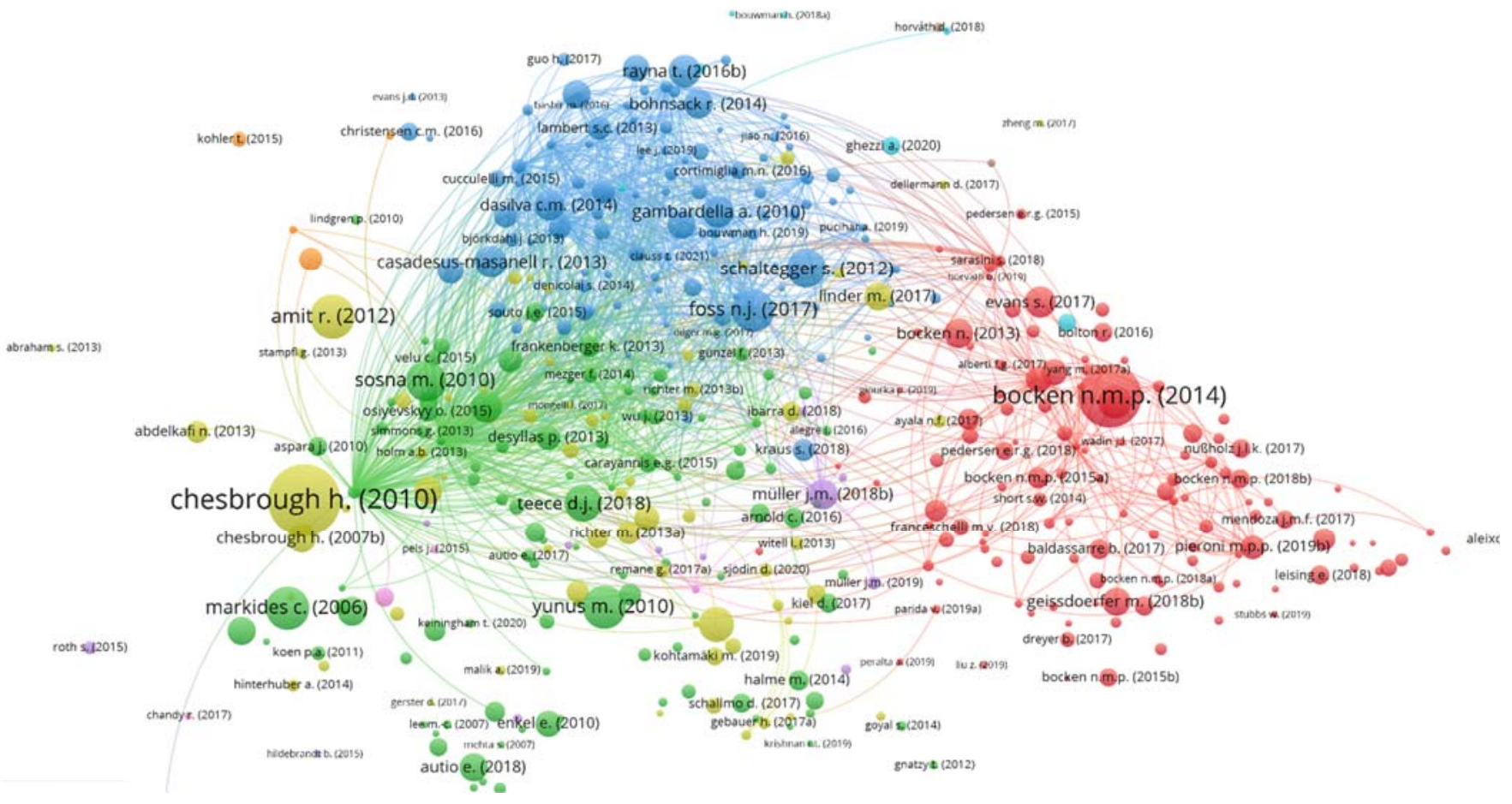

Figure 3. A VOSviewer bibliographic coupling document cluster analysis of the "business model innovation".

The overlay distribution of the studies shows that the SBMI field is more recent than the mainstream BMI (Figure 4). Nevertheless, it also indicates that all four streams are advancing in parallel. New studies are emerging in all four clusters, showing that, in line with Lüdeke-Freund's [66] observation, SBMI is emerging as a new research field rather than substituting mainstream BMI. 


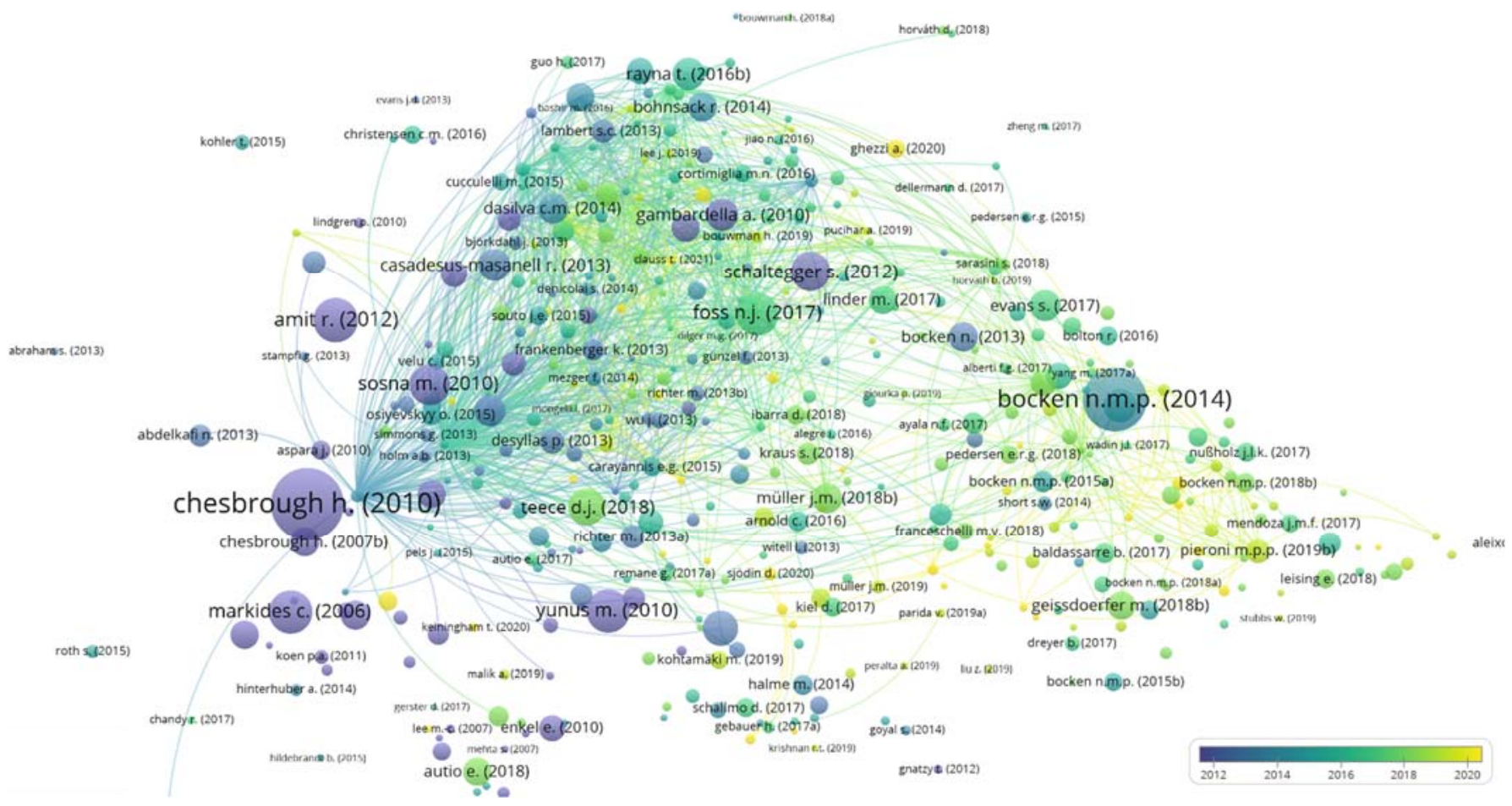

Figure 4. A VOSviewer overlay bibliographic coupling document cluster analysis of the "business model innovation.".

SBMI is close but separated from the service business model innovation, the yellow cluster (Figure 3), which is interesting considering the literature highlights the potential positive impacts of servitization and product-service systems in sustainability [39,67]. Tables 2 and 3 show the most-cited publications for SBMI and BMI, which supports the interpretation of the VOSViewer ${ }^{\circledR}$ analysis from the BMI field.

Table 2. Most-cited publications in the SBMI field. Source: Scopus, 10/10/2021.

\begin{tabular}{cc}
\hline Authors & Cited by \\
\hline Bocken, N.M.P. et al. [40] & 1246 \\
Evans, S. et al. [39] & 301 \\
Geissdoerfer, M., Vladimirova, D., Evans, S. [19] & 217 \\
Bocken, N.M.P., Short, S.W. [68] & 154 \\
Geissdoerfer, M., Bocken, N.M.P., Hultink, E.J. [69] & 152 \\
Bocken, N.M.P., Rana, P., Short, S.W. [70] & 146 \\
\hline
\end{tabular}

Table 3. Most-cited publications in the BMI field. Source: Scopus, 10/10/2021.

\begin{tabular}{cc}
\hline Authors & Cited by \\
\hline Chesbrough H. [65] & 1632 \\
Johnson M.W., Christensen C.M., Kagermann H. [71] & 1179 \\
Chesbrough H. [72] & 689 \\
Yunus M., Moingeon B., Lehmann-Ortega L. [73] & 597 \\
Foss N.J., Saebi T. [42] & 576 \\
Sosna M., Trevinyo-Rodríguez R.N., Velamuri S.R. [50] & 507 \\
\hline
\end{tabular}

Considering the publication sources, SBMI is majorly published in engineering and special purpose journals, with only a few published in business and management journals. On the other hand, BMI is more distributed. Although primarily published in business 
and management journals, it is also published in engineering and special purpose journals. Tables 4 and 5 depict, respectively, the demography of journals publishing BMI and SBMI.

Table 4. Quantity of SBMI publications by journals.

\begin{tabular}{cc}
\hline Journal 1 $^{\text {1 }}$ & Publications Count \\
\hline Journal of Cleaner Production & 15 \\
Sustainability (Switzerland) & 9 \\
Business Strategy and the Environment & 3 \\
Corporate Social Responsibility and Environmental Management & 2 \\
Emerald Emerging Markets Case Studies & 2 \\
\hline${ }^{1}$ Search query: "Sustainable Business Model Innovation" OR "Business Model Innovation for Sustainability".
\end{tabular}

Table 5. Quantity of BMI publications by journals.

\begin{tabular}{cc}
\hline Journal $^{\mathbf{1}}$ & Publications Count \\
\hline Sustainability (Switzerland) & 48 \\
Journal of Business Research & 39 \\
Journal of Cleaner Production & 35 \\
Journal of Business Strategy & 23 \\
International Journal of Innovation Management & 22 \\
\hline
\end{tabular}

${ }^{1}$ Search query: "Business Model Innovation" AND NOT ("Sustainable Business Model Innovation" OR "Business Model Innovation for Sustainability" OR "sustainable business model").

Analyzing with the VOSviewer ${ }^{\circledR}$, targeting the journals citation relationship through bibliographic coupling (the degree of sharing the same references), we notice the blue cluster, publishing more SBMI, centralized in the Journal of Cleaner Production and Sustainability (Switzerland). Journals oriented towards sustainability appear jointly in this cluster. The red and green clusters are closely related to one another and are slightly separated from the blue cluster. These are mostly publishing mainstream BMI (Figure 5).

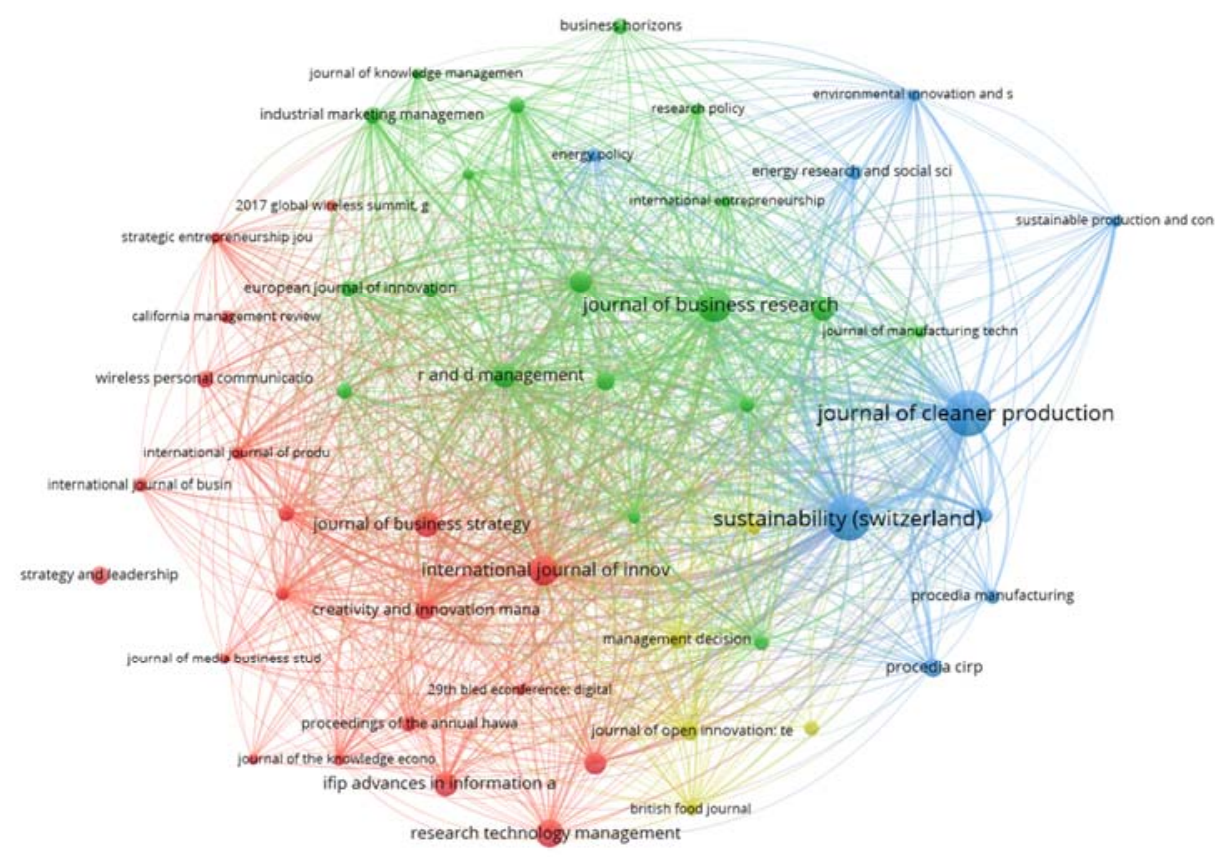

Figure 5. A VOSviewer bibliographic coupling cluster analysis between sources publishing BMI and SBMI. 
Taking a closer look into the overlay function (Figure 6), we can see more recent action on journals from the blue cluster (Figure 5) (SBMI and sustainability-oriented BMI) and green cluster (general management and engineering journals). The red cluster (Figure 5), which also holds entrepreneurship journals and proceeding conferences, seems to have less action. This is in line with the idea of BMI evolution to BMI management, emphasizing new ventures, capabilities for continual execution of BMI, and the rise of sustainability and digital transformation phenomena.
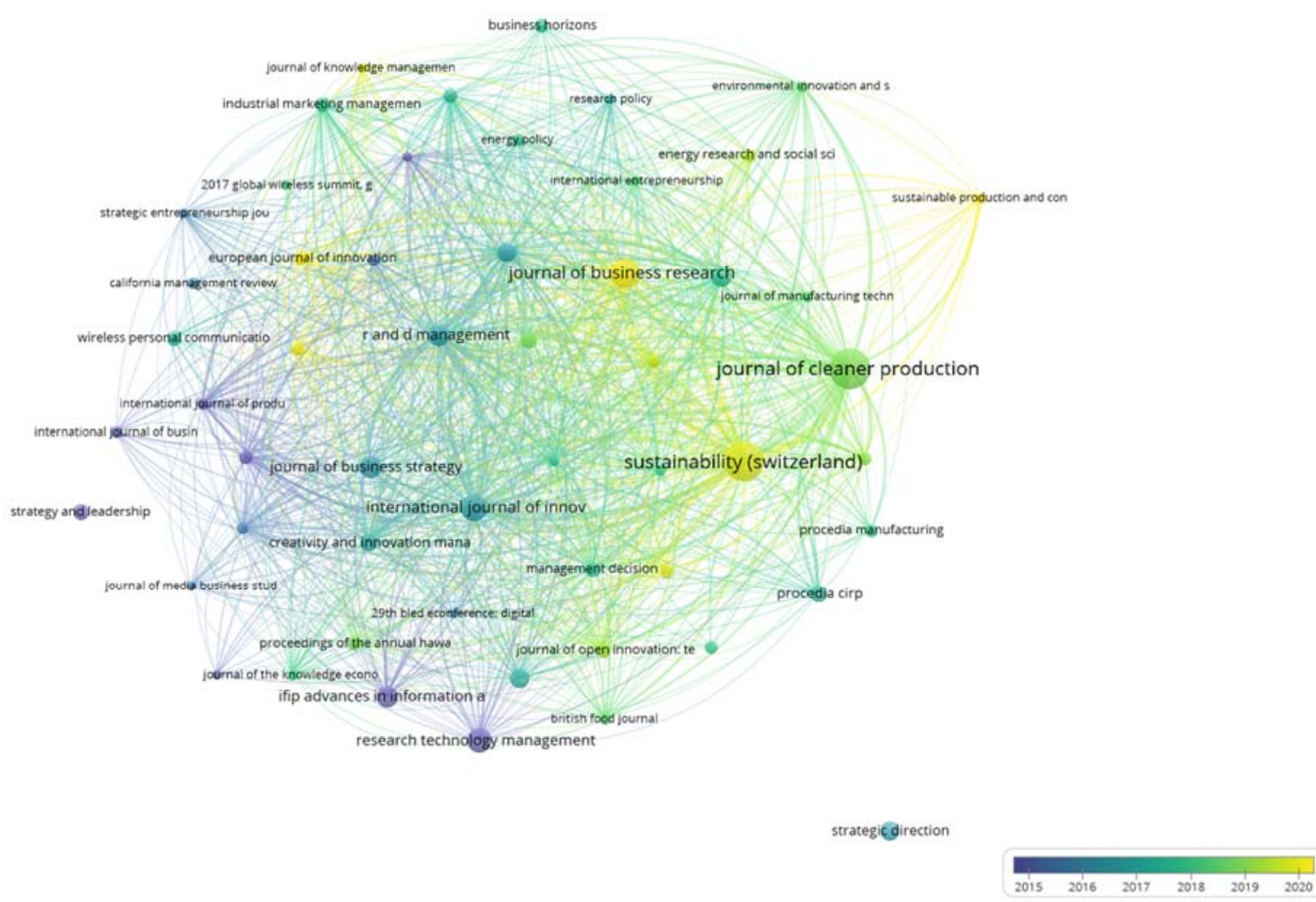

Figure 6. A VOSviewer overlay bibliographic coupling cluster analysis between sources publishing BMI and SBMI.

To deepen our analysis of each field's evolution, we analyzed the keywords (Figure 7). It is possible to identify five clusters. The red comprises terms related to sustainability, sustainable development, SBM, and SBMI. The blue cluster contains performance aspects, dynamic capabilities, BMI, etc. Finally, the purple cluster presents the terms startup, entrepreneur, competitive advantage, etc. The green and yellow ones are those close to each other, showing terms related to BM, digitalization, technologies related to digital transformation, service and service innovation.

When considering these keywords, regarding the period in which they were published, through the overlay function (Figure 8), it is possible to verify that we can highlight SBMI, dynamic capability, digitalization, circular economy, and startup among the most recent keywords. Among the oldest terms, we emphasize business model, firm performance, competitive advantage, and technology, which shows that these topics have been debated for a longer time. Combining both analyses, we notice that the BMI literature is moving towards further researching dynamic capabilities and capabilities for continual BMI in general, exploring the digital transformation phenomenon and understanding the relationship between incumbents and small and medium enterprises (SME) and startups. SBMI, in contrast, is more concerned with tools, experimentation, and design. 


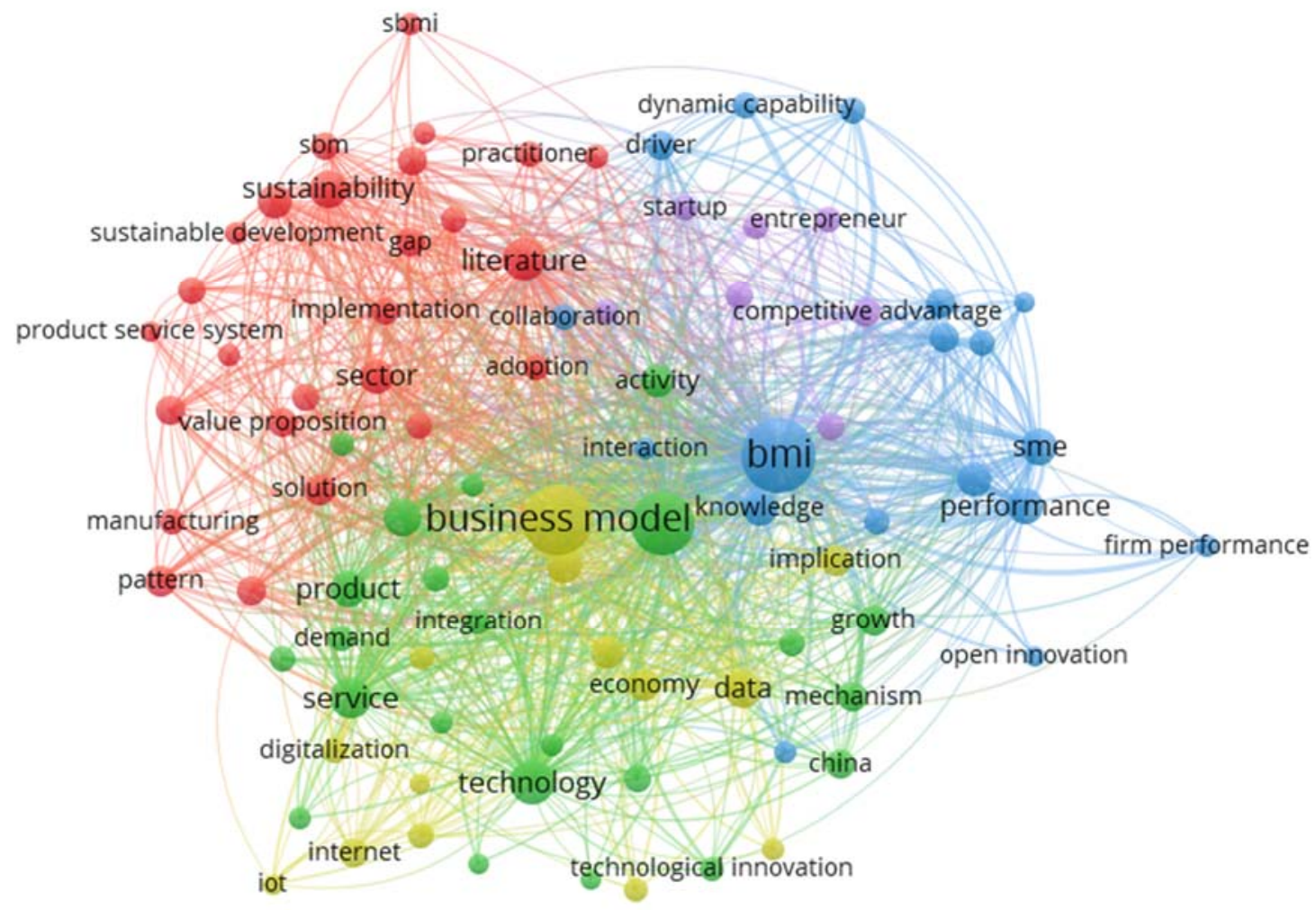

Figure 7. A VOSviewer analysis of keywords cluster analysis from the BMI literature.

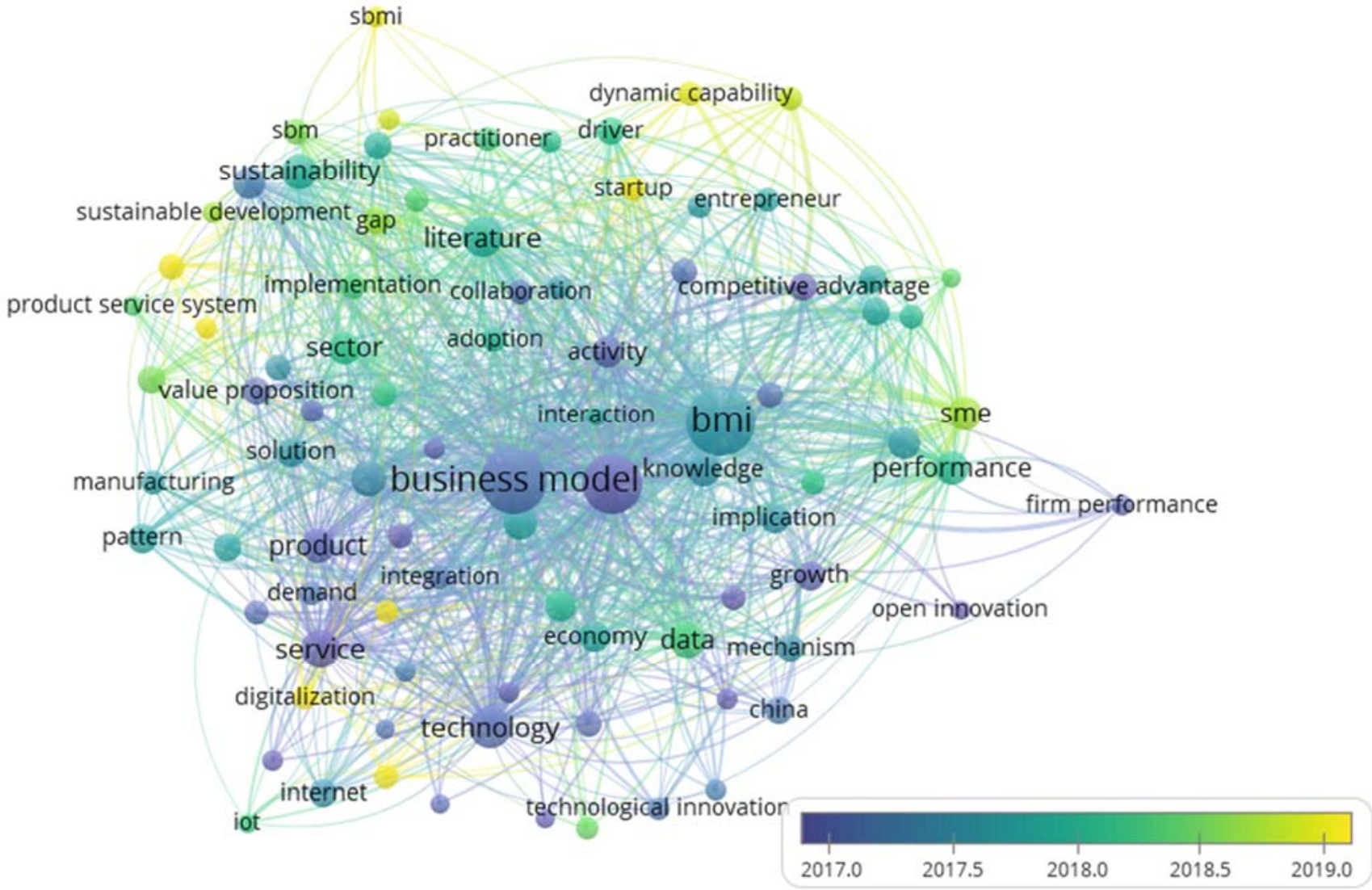

Figure 8. A VOSviewer overlay analysis of keywords cluster analysis from the BMI literature. 
To better understand the SBMI field's evolution, we move forward into taking a deep dive inside this literature through the SLR, opening up and making sense of the bibliometric analysis. Thus, we are understanding how to integrate existing literature into a comprehensive framework, taking the first steps towards systematic SBMI.

\subsection{Systematic Literature Review}

We organized the reviewed papers according to types of sustainability-oriented BMI. The SBMI literature presents several studies that do not cover all triple-bottom-line layers. Some studies focus on providing models that promote balance between the environmental and economic dimensions, which we classified as ecological BMI. Other studies focus on models that balance the social and economic dimensions, which we classified as equitable BMI. Studies that exclusively balance environmental and social dimensions, which would be classified as altruistic BMI, were not found, which makes sense because to be an innovation it needs to have market acceptance, and therefore, a solid economic pillar. Finally, we classified studies that comprise all dimensions of the triple bottom line as SBMI.

Table 6 presents the type of sustainable-oriented BMI based on publications that support the performed categorization. Finally, we connected such categorization and SBMI literature with sustainable development goals (SDG). The intent was to provide a broader view of how SBMI studies are contributing to these goals.

Table 6. Sustainability-oriented BMI.

\begin{tabular}{ccc}
\hline Type of Sustainable Oriented BMI & SDG & Supporting Publications \\
\hline $\begin{array}{c}\text { Altruistic BMI: Environmental } \\
\text { and Social }\end{array}$ & - & - \\
\hline
\end{tabular}

$2,3,12$

Equitable BMI: Social and Economic
"The BC has a positive influence on the society because data entries are digital and immutable. Information about quality (e.g., geographic origins and freshness), safety (e.g., healthiness and no modification) and sustainability (e.g., fair-trade) of the products are guaranteed by the BC, which ensures data transparency, integrity and security." - Tiscini et al. (2020, p. 1628) [74]

"The designers of SKN can obtain a stable source for design projects, a wealth of learning materials, and opportunities for communication between partners and peers. [ . . ] intelligent matching with the talent pool, which consists of designers and project resources provided by architecture design institutes. I ... I SKN may increase their revenue, improve their design ability, and supply them the freedom to the work time arrangement and the choice of design projects"- $-\mathrm{Hu}$, Huang, Cheng and Lu (2019, p. 6) [75] 
Table 6. Cont.

\begin{tabular}{lc}
\hline Type of Sustainable Oriented BMI & SDG \\
\hline & \\
\hline & 12 \\
\end{tabular}

$7,11,12,13,14,16$

Ecological BMI: Environmental and Economic
Supporting Publications

"British Sugar has modified and extended its business model over a period of decades to utilize internal waste streams to create new coproducts and internalize environmental externalities (i.e., waste streams) within their business model."-Short et al. (2014, p. 606) [76]

"[ ... ] they use only biodegradable products (such as cutlery, glasses and napkins) and sustainable facilities to avoid producing $\mathrm{CO}_{2}$ (e.g., an electric oven and electric delivery bikes)."-Franceschelli et al. (2018, p. 2487) [77] "By developing a value proposition that combines technological advancements with a deep understanding of user needs in order to induce behavioural change, the study also contributes to research on excessive energy consumption. Specifically, this would be a situation in which the demand for energy outpaces the sustainable generative capacity of the ecosystem [...] Reducing energy consumption is a priority"-Baldassarre et al. (2017, p. 176) [78]

"Fairer share of economic value through integrated contract. Environmental value through increasing transparency of farm-level practices with a view to improving environmental performance." [ ... ] "Environmental value destruction avoided through reducing crop wastage. Risk is more evenly distributed." [...] "The complementary logic prioritizes both environmental and economic value in the network resolving this trade-off."-Brennan and Tennant (2018, p. 626) [79] "[ ... ] can be categorised by the sustainable business model archetypes identified by Bocken et al. (2014): maximizing material and energy efficiency ('data monitoring and analysis' and 'remote webcam support'), encouraging sufficiency ('per-use fee'), creating value from waste ('take-back service') and adopting a stewardship role ('upstream engagement')."-Heyes et al. (2019, p. 629) [80]

"These CE actions (furniture, mugs and food containers, appliances and lighting) have been considered a key starting point to help overcome organisational and operational barriers

(Table 1) and redesign the university's business model (Figure 3) by taking incremental steps."-Mendoza et al. (2019, p. 564) [81]

"This study resulted in three VUs covering (1) the size (dimension) of the product does not match what the consumer needs; (2) quality does not match consumer expectations, and (3) the remaining material (rattan pieces) still has economic value."-Burhan et al. (2021, p. 18) [82]

"Kaaita incorporates elements of several sustainable business model archetypes, particularly, creating value from waste, adopting a stewardship role, encouraging sufficiency and repurposing for society/environment."-Pearse and Peterlin (2019, p. 156) [83]

"not to use synthetic pesticides, fertilizers, growth regulators, feed additives and other substances in the production of fresh products."-He and Ortiz (2021, p. 7) [84]

"No plastics were used as the bottles were made of glass, which is sustainable $[\ldots]^{\prime \prime}$

"One business model innovation mentioned in the economic canvas, the launch of the first certificated vegan wine, had an effect on the environmental perspective of the firm's business model."-López-Nicolas et al. (2021, p. 10) [85] 
Table 6. Cont.

\begin{tabular}{|c|c|c|}
\hline Type of Sustainable Oriented BMI & SDG & Supporting Publications \\
\hline $\begin{array}{c}\text { Sustainable BMI: Social, } \\
\text { Environmental and Economic }\end{array}$ & $1,7,8,9,11,12,14$ & $\begin{array}{l}\text { "Econyl is a polyamide made from } 100 \% \text { recycled raw } \\
\text { materials that include postconsumer waste such as fishing } \\
\text { nets carpets, clothing, rugs and rigid textiles, as well as } \\
\text { preconsumer waste such as oligomers, scraps and others } \\
\text { generated from the production of Nylon 6" [ . . ] "The main } \\
\text { source of regenerated nylon is made of fishing nets recovered } \\
\text { in the seas, oceans and aquaculture" [ . . . ] "To date, the } \\
\text { company's turnover coming from circular economy had grown } \\
\text { by 6.5\%" "[ . . ] the relationships between RigenNylon and } \\
\text { the waste collectors were crucial for the success of the new } \\
\text { SBM [ ... ] joined Net-Works, an umbrella business that } \\
\text { involves a partnership between a carpet manufacturer } \\
\text { (Interface), a yarn producer (namely RigenNylon) and a } \\
\text { conservation charity (Zoological Society of London, known as } \\
\text { ZSL)"-Biloslavo et al. (2020, pp. 1651-1652) [10] }\end{array}$ \\
\hline
\end{tabular}

This literature organization process revealed an important research stream based on SBMI outcomes. This research stream provides (and analyzes) pictures of new SBMs, targeting what specific elements changed and the impacts on society, environment, and profit. It usually relies on case studies and either focus on a solution (social purpose or environmental purpose) or a technology (Blockchain, IoT, etc) $[74,77,86]$. The key idea is to show interlinks between generating economic value and social and/or environmental value $[67,68,87]$, delivering value for multiple stakeholders $[76,85]$. The literature often uses a BM visual tool to describe these new BMs, such as the Triple Layered Canvas and BM Canvas [74,77], and archetypes [41,88].

The emphasis is usually on showing environmental and social value. Although mentioning economic value, it is in a second plane and accompanies the BM logic. Notable studies targeting the economic issue tend to look more carefully into customers' willingness to adopt new sustainable-oriented BMs, such as Yip and Bocken [41] in the banking sector, and Sattari et al. [89] who studied Circular Business Models. Short et al. [76] attempt to uncover this issue by evaluating value-creating complementarities between environmentally friendly BMI and economic gains.

Evaluating SBMI outcomes and showing potential means to create complementarities between triple-bottom-line sustainable dimensions is in line with the most recent research on BMI. Accordingly, it is acknowledged that a BM's core element is the creation of virtuous value cycles, building complementarities that add value [15]. When translating this idea to the SBMI reality, it is vital to develop such complementarities between all three dimensions, adding value for multiple stakeholders, including society and the environment [85].

Despite this research stream's importance, if we consider SBMI management, it is essential to explore other elements. In the following subsections, we examine antecedents, tools, and processes regarding managing SBMI.

\subsubsection{SBMI Firm-Level Antecedents}

This is an emerging research stream and has few papers exploring it. Instead of focusing on the components of newly developed SBM and on specific tools to help the process, this research stream targets organizational phenomena that effectively lead to SBMI. Hence, the focus is on how organizational design [9] and structure [90], along with strategy $[9,75,90]$ and operational configuration (mainly leveraging startups founders) [91], shape the organization's capability for continual deployment of SBMI [14]. The stream also provides the relevant capabilities for SBMI. Some examples are legitimizing activities with stakeholders [10,92]; influencing supply-chain leaders to create adequate supply networks for embracing the new SBM paradigm [79,93]; searching to understand supply network tensions, conflicting interests [94], and complementary synergies to improve 
collaborative innovation performance; educating customers on new paradigms [95] such as sufficiency-driven SBM [68]; SBMI teams' adoption of tools and practices [83]; and change management $[14,96]$. Table A1 in the Appendix A provides a clear definition of each of the antecedent's key concepts, the supporting publications, and the deepness of investigation of each element.

Therefore, similarly to BMI, there are key factors that an organization has that ultimately enable or hinder it from (1) conducting SBMI efforts in the first place and (2) having success with these efforts. It points towards an analogous direction to mainstream BMI: dynamic capabilities and organizational design. Organizational design is critical since it positively or negatively influences the organizational environment for dynamic capabilities, which are responsible for successful SBMI $[9,14]$. It can either improve dynamic capabilities or hinder it, as it shapes beliefs and values, materializing into strategic orientation and operational practices [9].

The SBMI literature also emphasizes the relevance of leadership's vision [96], values, and beliefs $[9,83]$. As the literature has few large companies' and incumbents' cases featuring a high level of sustainability-oriented entrepreneurship, the relationship between leaders' sustainability orientation on the one side, and business processes and capabilities on the other, could be less straightforward when moving into larger organizations, as there are larger vested interests and more complex hierarchies and relationships.

Figure 9 depicts the summary of SBMI literature on firm-level antecedents. We built the framework considering the strategic level, the capability level, and the individual level. At the strategic level, organizational design plays a major role in shaping values, beliefs, strategy orientation and definition, and the underlying organizational structure. It exerts a top-down influence on the dynamic capabilities level. At this level, we organized the capabilities from the literature for executing the SBMI process. At the bottom level, the individual incentive schema, the people's beliefs, and orientation towards sustainability and innovation exert a bottom-up influence on the SBMI capabilities.

\subsubsection{Design Tools and SBMI Process}

A research stream is focused on building and proposing design tools to support the SBMI process. It primarily considers SBMI characteristics that differ from mainstream BMI, which renders mainstream BMI-related tools limitedly useful with variations. It largely bases its tools on the Business Model Canvas $[80,97,98]$ and creates variations adding multiple stakeholders [84] relevant for sustainability. Output examples are the triple-layered Canvas [85,99], the Prototyping Canvas [100], and the Sustainable-Oriented Service Innovation (SOSI) tool [98].

Considering the SBMI process, the research stream usually highlights the lean startup and the customer development [100] approaches, which are process-supporting tools. This means understanding the process as identifying an opportunity [95], finding a solution, designing a BM, and implementing the BM in practice [69]. Additionally, the rationale behind the process is iterative by nature, with multiple feedback loops, experimentation and fast knowledge generation while consuming low resources $[69,100]$. Considering the importance of linking the SBMI process with the overall strategy, this literature stream also proposes building a business case [81], implementation of road-mapping [80,81], and prioritization techniques [80]. Short et al. [76] also emphasize strategically aligning with the core business, creating complementarities and complementary assets with stakeholders [101], hence effectively managing paradoxical tensions that arise and overcoming the limited thinking that achieving sustainability entices losing economic performance [90,102].

Thus, the stream combines special-purpose tools that aggregate SBM specificities to this process, mainly targeting the fuzzy front end by filtering and identifying sustainable opportunities $[80,103]$ and the relevance of including a wide variety of stakeholders beyond shareholders and business partners [104,105]. 


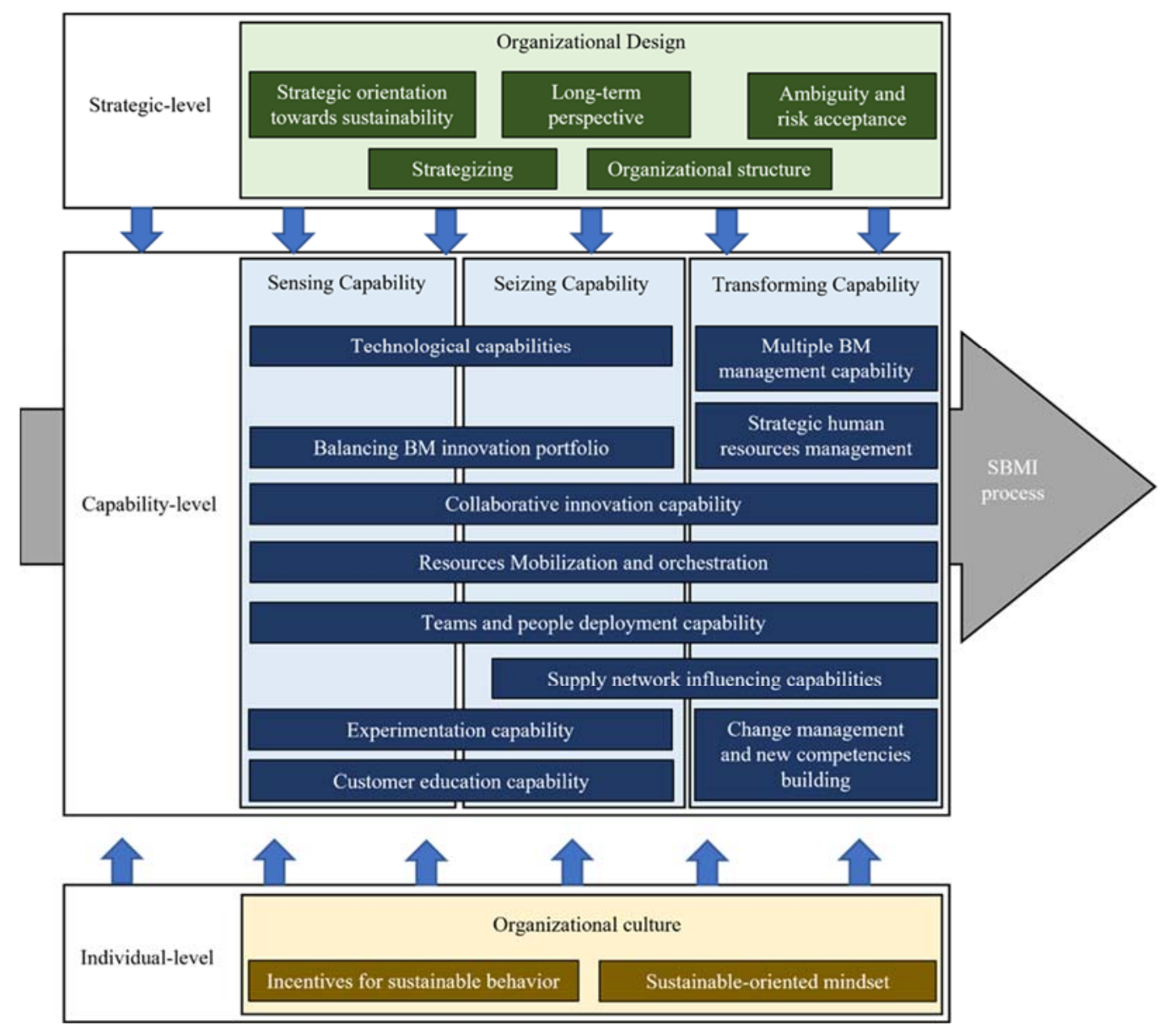

Figure 9. Summary of SBMI literature on firm-level antecedents.

Therefore, this research stream shows the underlying assumption that design tools are the key to successful SBMI [69]. This notion means that the differing characteristic from mainstream BMI is usually related to two key aspects. First, SBMI differs from BMI since it needs filtering-down opportunities that are sustainable by nature [106], creating a sustainable value proposition [82]. This first element reflects the extensive effort to build design tools for identifying sustainable opportunities and diagnosing value-uncaptured dimensions [107]. Second, this stream highlights the need to include more stakeholders into the SBMI process, especially those affected by it [70], which goes beyond financiallyand capability-related partners as in mainstream BMI. The reflections of this notion are the effective inclusion of cocreation models [80] and stakeholder value mapping [70] in the innovation process. This has largely focused on design thinking and value stakeholder mapping as the main associated tools.

To better structure the literature, we built the framework depicted in Figure 10, fitting the SBMI process into the dynamic capabilities' framework. We also organize the tools, methods, activities, and practices into each SBMI stage where they are most applicable. We provide in Appendix A Table A2 the description of the key concepts, explaining their connection to each SBMI process stage and the supporting publications. 


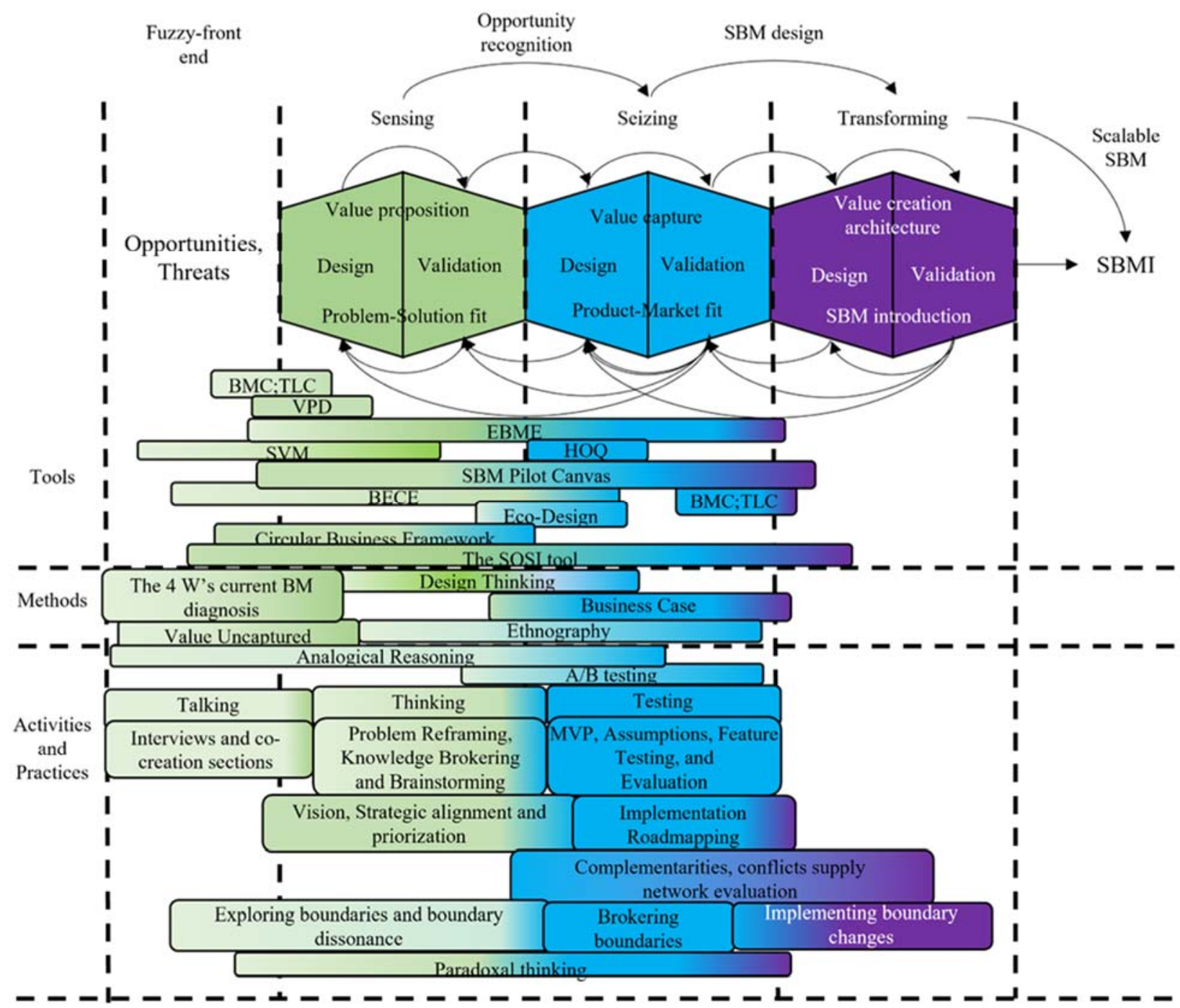

Figure 10. SBMI management framework.

\section{Discussion}

The review developed throughout the paper used two different methodological approaches. From such approaches, we investigated the relationship between SBMI and BMI literature. From observations of our results, we identified gaps that can benefit from better integration between BMI and SBMI. We discuss these gaps in the next subsections.

\subsection{Gap 1: Degree of Sustainability: Are the SBMs Fully Sustainable or Better Than Before?}

This research gap relates to the outcome of SBMI, the definition and implementation of SBMs. Table 6 in the SLR showed that most SBMI studies consider a SBM those BM that present any feature more sustainable than the previous BM, depicting the outcomes of SBMs as final, well-defined solutions. Most studies target the environmental dimensions, particularly the SDG 12 of "responsible consumption and production", without considering social or even other environmental dimensions. At the same time, studies often cite the complexity of measuring the resulting SBM's degree of sustainability, hence, highlighting the existence of rebound effects (i.e., adopting a potential sustainable-oriented solution leads to worsening rather than improving) and the impossibility of knowing and predicting ex ante how sustainable a BM is in reality [100]. This characteristic draws attention to the fact that the SBMI could possibly be "better than before" than fully sustainable BMs.

There are interesting emerging research fields that specifically target ecological or equitable BMI. For example, circular BMI has made interesting advancements regarding the 
challenges and means to overcome them for enabling the circular economy [108]. Social BMI is another interesting strand looking specifically for the bottom of the pyramid [109], frugal models [110], reducing poverty [73], alleviating hunger [88], and increasing equality [75]. The SBMI literature benefits from these studies, especially considering the need to understand specificities associated with each effort towards sustainability. However, we believe that SBMI's focus needs to be on accomplishing full sustainability, orchestrating the different paths to, in a combined manner, propose means to reach sustainability for the triple bottom line. As shown in Table 6, however, many SBMI studies target only a branch of sustainability, remaining as an intermediate step towards achieving full sustainability.

We propose to address SBMI initiatives as an ongoing, never-ending process. Hence, we recommend that studies should purposefully consider these three macrodimensions: (1) Equitable BMI, when the BMI effort also addresses a social dimension, encompassing the social BMI literature. There is no significant effort to reduce environmental impacts. (2) Ecological BMI, when the BMI focuses on diminishing environmental damage, such as reducing $\mathrm{CO}_{2}$ emissions, reducing waste, and inducing a circular economy. It implies no direct impact on society. Here, we would classify the emerging circular BMI primarily in this research stream, though we recognize that circular BMs may systemically affect society through changes in consumption behavior and concept, through labor-intensive services, among others. Finally, (3) sustainable BMI addresses all triple-bottom-line dimensions, mitigating environmental damages through eco-innovation for instance, while also, for example, alleviating poverty and increasing access to basic needs such as water and energy. A more detailed dive into potential microdimensions is presented by Lüdeke-Freund et al. [5].

It is at this level that SBMI literature should focus, purposefully leveraging on advancements of the intermediate substreams of equitable and ecologic BMI to reach powerful means for a continuous search for sustainability. In this context, we propose the following research questions: What are the specific processes, tools and elements of social and ecological BMI? How do we integrate them to keep moving towards a fully SBM? How do we overcome specific challenges of them?

Despite the conceptual nature of this gap, its consequences are significant, for it may break down the systematic and continuous search for full sustainability. As we argue throughout this study, sustainability has the characteristics of a wicked problem. It is almost impossible to understand its causes and effects completely, is often elusive due to inherent systemic complexity, its problems and solutions change over time, and it does not display right-or-wrong, but better-or-worse scenarios (see Batie [26] for a discussion). Hence, SBM is a continuous search for, not a solid, well-defined goal. This places emphasis on the problem of looking at SBM as static units. Instead, it makes sense to look into underlying organizational phenomena that allow for systematic SBMI, continuously pursuing "better than before" scenarios, suitably treating SBMI as a wicked problem. The next gap looks inside this issue of the antecedents of a "sustainable business engine creation" through the dynamic capabilities lens.

\subsection{Gap 2: The Antecedents for SBMI: Are Dynamic Capabilities the Same for Both SBMI and BMI?}

Studies often cite dynamic capabilities as the core firm-level antecedent for executing the SBMI process [14], which is aligned with the BMI literature [42]. Considering that a set of capabilities comprises the functioning of a company [12], it makes sense given that SBMI success depends on the creation and/or transformation of capabilities and processes that underlie any BM $[13,111]$. However, as we show in Section 4.2.1, even though the analyzed publications recognize the dynamic capabilities' relevance for successful SBMI [112], there is a lack of studies aiming to uncover its distinctive dimensions for SBMI. One notable exception is Inigo et al. [14], whose study attempts to deepen our understanding of dynamic capabilities for sustainability [112]; the authors, however, highlight the need to study this further. We propose, in Figure 10 and Table A1, an abstraction from the publications addressing antecedents. We classified and defined the mapped antecedents as part of 
the different dynamic capabilities of sensing, seizing and transforming. Nevertheless, the framework remains incomplete, as there are few studies targeting these antecedents, especially at the capabilities level.

Opposite, within mainstream BMI the dynamic capabilities research stream has advanced significantly and provided good understanding of their distinctive dimensions $[13,15,111,113,114]$. Understanding these dimensions for BMI assists in measuring dynamic capabilities, e.g., a team's ability to learn is a relevant dimension of sensing capability, the top management team's strategic orientation and its influence on the BMI portfolio management influences sensing and seizing capabilities, and so on [15]. Therefore, this supports a diagnosis of their current situation, hence, allowing systematic managerial action to potentiate these capabilities and pursue BMI in long term. Despite Pieroni et al. [21] and Inigo et al. [14] who call for further studies on dynamic capabilities for SBMI, it has, to date, not evolved. Bocken and Geradts [9] is the first attempt to uncover organizational design mechanisms within this research stream. However, the dynamic capabilities dimensions for SBMI are not the focus of the study. The bottom line is that we still do not know much about capabilities' dimensions that enable pursuing SBMI systematically as a long-term goal.

Therefore, we propose the following question: Is there a set of distinctive dimensions for dynamic capabilities in SBMI that are not the same as in mainstream BMI? Considering the often-cited complexity regarding SBMI [100], it may demand specific dynamic capabilities' dimensions for sensing, seizing, and transforming SBM design into SBMIs. The prominence of the "design-implementation gap" is a good illustration of this point [115]; SBMI literature largely focuses on design tools and experimentation as the approaches for conducting SBMI. This means mainly influencing sensing and seizing capability, in which the output is a SBM design. This focus is far away from understanding capabilities' dimensions for SBMI. Thus, dynamic capabilities for SBMI are still hard to measure, and as a consequence hard to manage.

\subsection{Gap 3: The SBMI Process: The Role of Open Innovation}

In Section 4.2.2, we build a processual framework of SBMI, along with supporting tools, methods, activities and practices. However, there was a clear absence of publications targeting the role of open innovation, considered critical for mainstream BMI, with notable exceptions of [116-118]. This is surprising, considering the high relevance of multiple stakeholders' integration and engagement for SBMI [119]. Further engagement with, and understanding of contributions from, different stakeholders in SBMI needs further consideration in future research works. The research stream on circular BMI has made advancements in this direction, especially targeting the collaborative innovation process, proposing tools [120], and discussing the applicability of open innovation for collaborative circular BMI [108]. There is also a growing literature on open innovation and sustainabilityoriented innovation, especially targeting technological innovations [121-123]. The research line targeting sustainability-oriented technologies has grown, but this needs to be linked to the SBMI level, calling for further research on the subject to better grasp the SBM innovation funnel and its management. In this regard, we propose the following research questions: How can open innovation improve the adoption and performance of SBMI efforts? What are the potential contributions of different types of stakeholders to SBMI?

5.4. Gap 4: The Lack of Tools, Methods, Activities and Practices Supporting the Transforming Stage of the SBMI Process

Design tools and the SBMI process are a more deeply explored field. We derived an overall framework of the iterative SBMI process, with three stages of sensing, seizing and transforming. The overall SBMI process is roughly the same as the BMI process. The SBMI literature offers sustainability-oriented tools, methods, and practices supporting its process's specificities. However, they often target sensing and seizing stages of the SBMI process, supporting the identification of opportunities, validation, primarily targeting the SBM design. 
When moving forward to implementation, from the final seizing stages through transforming, there is a significant gap of approaches, contributing to the "design-implementation's" gap persistence. An important research question for future research is: What should be the tools, methods, activities and practices supporting the transforming/implementation stage of the SBMI process?

This lower abundance of approaches for transforming and effectively leading implementation is also true for the BMI literature, which has, nevertheless, made significant advancements. BMI studies emphasize that reaching out to the transforming capability demands solid sensing and seizing capabilities rooted in the organizational structure [15]. This means to keep the funnel running (in an economically feasible manner) until reaching the transforming bottleneck. After this point, recent advancements highlight change management [65], organizational ambidexterity [51,124] in managing multiple BM [25], organizational design for the new BMs [125,126], supply network and regulatory scenario orchestration [127], organizational culture, and leadership [128], resources and capabilities building [129] and strategic human resources management [130].

\subsection{Gap 5: SBMI Outcomes and Their Connection to Competitiveness and Performance}

BMI literature arose and acquired momentum by showing (appealing) BMI outcomes, such as disruption with new BM displacing well-established business paradigms and huge performance (economic) gains. Moreover, it also suggested that superior technologies are only game-changing when they accompany a sound BM [131]. Some examples of this feature are Uber and Taxis [13], Airbnb and Hotels [132], Netflix and Blockbuster [133], Fintechs, and Incumbent Banks [134], among others.

This is effectively demonstrated in a Christensen's [135] innovators' dilemma dynamics in the BMI literature. More importantly, the BMI literature has also shown a change in the competitive pattern, from technological innovation to BM innovations; it entices Schumpeterian creative destruction [136] in the sense that one either does and seizes benefits or does not do and probably dies. It is also part of the increasing interest of companies to pursue BMI, urging companies to restructure themselves to create BMI management capabilities [15].

SBMI emerged following a different path. The interest in the topic is not led by disruption or examples of cases that revolutionized a particular industry. On the contrary, the majority of SBMI examples usually show modest economic results. SBMI literature arose with the need to address sustainable development needs, primarily focusing on solving environmental and social issues. This is not to say that this reason is not appealing and of utmost importance. However, the competitive business landscape demands accomplishing economic aspects and market disruptions. This is reflected in the definition of an innovation, which is no longer an invention or a design only when it successfully reaches the market and is scalable. SBMIs need to result in superior competitive advantage, therefore challenging the mainstream business paradigms.

Short et al. [76] is an exception. The authors do show environmental gains through BM evolution. Still, they deliberately show virtuous value creation cycles, combining environmental gains to the economic dimension, depicting performance gains and competitive advantages. Doing so illustrates paths to overcome existing thoughts that there are trade-offs between ecological and economic value. Yip and Bocken [41] is another example, deliberately linking SBM adoption in the banking sector to customer loyalty and traction, therefore improving performance. We propose future research to focus on the following question: What are the impacts of SBMI outcomes in companies' performances and competitiveness?

\subsection{Contributions}

The findings presented in the results section effectively address our research goals, which were defined as (1) exploring the relationship between BMI and SBMI literatures in 
an organized manner, and (2) identifying the antecedents, capabilities, tools, and processes that should be part of a systematic approach to SBMI.

Particularly, the bibliometric analysis showed how the BMI and SBMI literature has been developing, with SBMI spinning out at an early stage from BMI and evolving in an independent manner. Indeed, we found that there is little integration when viewed through the VOSViewer lens. Through the bibliographical coupling analysis, it was possible to check that the authors and journals of BMI studies are different from SBMI ones. Additionally, we see that while BMI is moving forward to deepen understanding of its antecedents for systematization, SBMI's focus is on experimentation.

Despite this scarce integration, it seems there is no barrier regarding the future development of the SBM and SBMI fields in a more integrated way. Literature on SBMI provides frameworks, archetypes, and definitions. At the same time, many studies point out the gap related to implementation management. In this regard, integration with the BMI body of knowledge could be important for SBMI. The presented SLR explores how SBMI relates to BMI management. We organized the SBMI literature regarding its outcomes, which helps in defining sustainability-oriented BMI categories, and we created a framework of firm-level antecedents, design tools, and processes for SBMI.

The findings of our research advance the literature by promoting paths for managing SBMI systematically and for consistently informing managerial actions. Ultimately, this could lead to enhancing the practical adoption of SBMI.

However, we observed critical gaps in the SBMI literature based on the results, especially considering the BMI advancements. In Section 5.5, we discussed and analyzed such gaps, providing research questions for future works. Figure 11 summarizes the main contributions of our paper considering the bibliometric analysis and SLR results and the consequent discussions. This figure is composed of three layers. In the first one, the main findings from the bibliometric analysis are presented; in the second one, the findings from the SLR are summarized as well as the gaps identified in this analysis; in the last layer, the lessons from BMI and future research paths, addressing the gaps listed, are provided, indicating relevant propositions for future research.

\subsection{Limitations}

Although this study's goals are to push forward the concept of SBMI management, emphasizing what we can learn from the BMI literature, this study also has its limitations. Previous reviews, such as Bocken et al. [40], used correlated keywords (circular, green, social, among others). Considering our focus, we narrowed down the SLR's search strategy to capture studies that explicitly deal with BMI for sustainability, without using correlated keywords such as circular BMI or BMI for the circular economy, social BMI, green BMI, among others.

Considering the SBMI field is now more mature [66], we were able to focus on SBMI keywords. This was not true during previous reviews, such as by Bocken et al. [40], for which the time of execution meant that combining related keywords made more sense. Nevertheless, one interesting perspective should capture how these correlated fields' advancements help answer the existing gaps to frame the systematic SBMI. As we emphasized in the discussion section, the identified gaps can surely benefit from integrating these research streams. SBMI management, as we propose, will certainly call for different sustainability-oriented BMI, which also helps us understand the specificities surrounding each effort. Certainly, a social-oriented BMI differs from a circular BMI. Further work could also explore the overlaps, synergies and opposite views of the BMI, SBMI, circular BMI, service BMI and social BMI disciplines all together.

Our study also focused on defining SBM not as a goal but as an ongoing continual effort, and we also point out that sustainable development will require multiple companies and supply networks of companies working together and transforming through SBMI. Hence, studies targeting the supply-chain level and the buildup of the supply network of sustainable companies would add value to our knowledge regarding SBMI. Our study does 
contribute to this line of thinking. Increasing the adoption of SBMI by numerous companies can help to achieve a shared vision between supply-chain actors, facilitating the adoption of sustainability-oriented BM by multiple actors. However, policy-oriented studies can combine to provide greater motivation and an adequate environment that favors SBMI. Some examples include adding taxes to unsustainable actions, educating society, and other institutional factors that direct companies' needs towards SBMI.

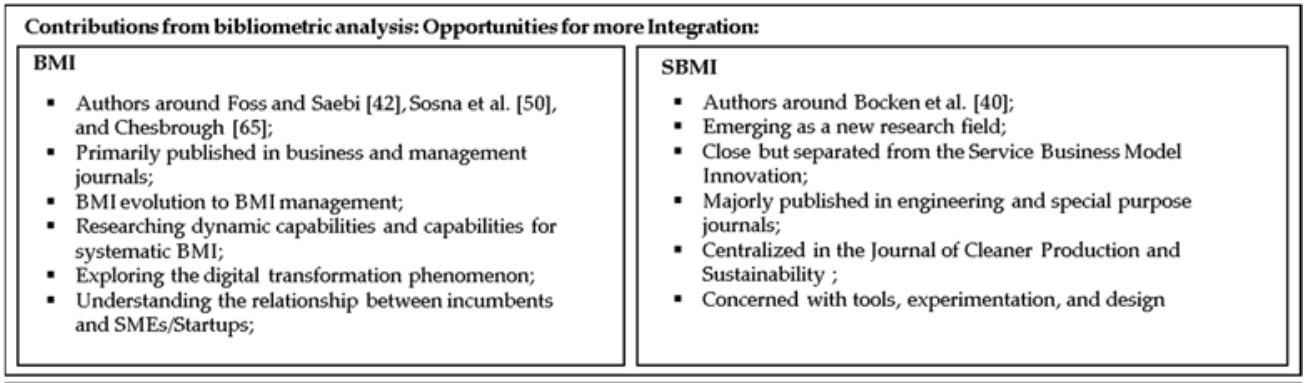

SLR Contributions: Framework for systematic SBMI and critical gaps from BMI analogical reasoning
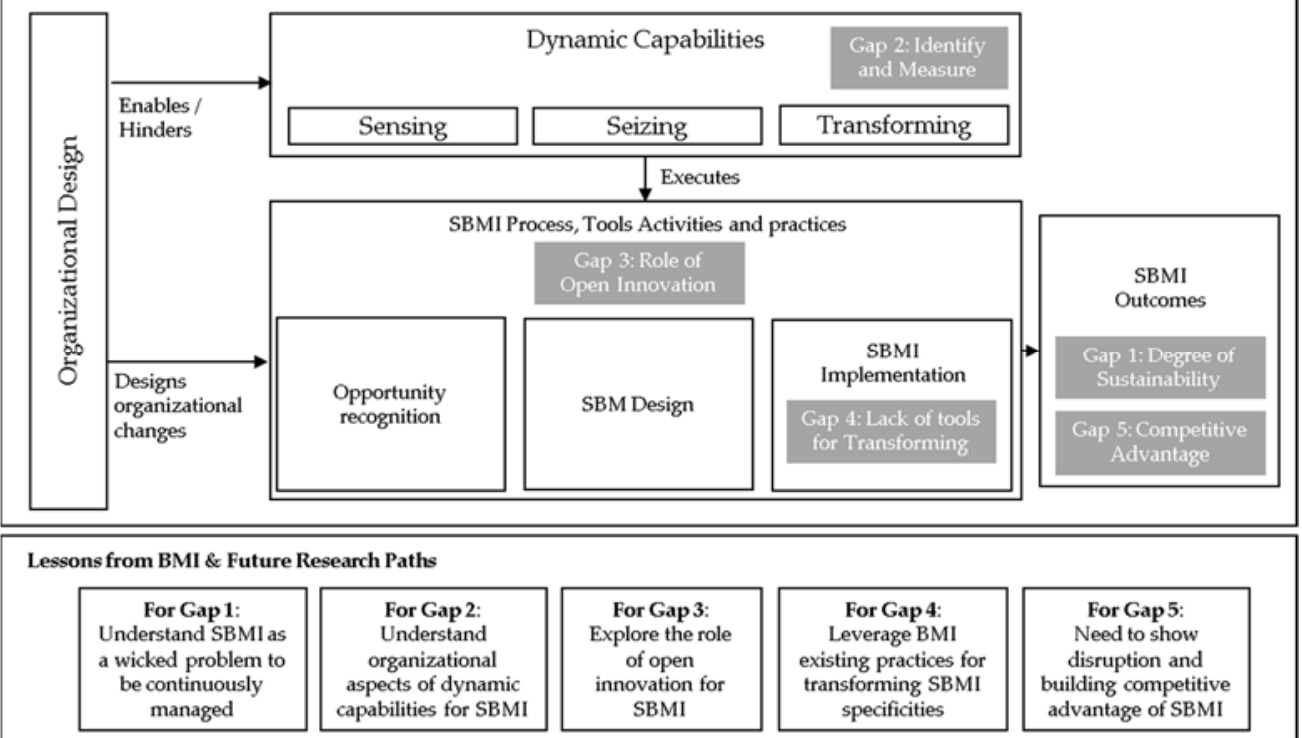

Figure 11. Framework for Systematic Sustainable Business Model Innovation.

\section{Concluding Remarks}

Developing a sustainable company is a long-term, never-ending quest of innovation and a never-ending pursuit of SBMI through "better than before" series of subsequent BMs towards fully sustainable BMs in the future. This dynamism calls for understanding how companies can develop the capability to continually and systematically conduct SBMI. This is not to say that local solutions, case studies, and specific examples of SBMI are not necessary. Instead, we argue that the SBMI literature should pursue the goal of understanding how to develop such capability, by, for example, building on BMI literature's advancements as well as deeply understanding the specificities of available exemplary solutions and case studies.

To the best of the authors' knowledge, our study provides the first attempt to organize, interpret, and analyze the SBMI literature to build a coherent framework for continuous and systematic SBMI. However, SBMI is still a recent research stream with many opportunities for research, and this work has uncovered five research gaps leading to a set of future research questions.

As BMI literature is more advanced and many companies are trying to create capabilities for systematic BMI, we set out to provide this knowledge to shed light on some paths 
for SBMI literature advancement. In particular, we corroborate the notion of dynamic capabilities as primary antecedents for SBMI. The still-generic view of DC as sensing, seizing, and transforming means that the concept is, at the same time, applicable to any innovation effort but does not effectively inform how to create such capabilities in practice. Thus, it calls for a definition of what DC for SBMI looks like in terms of observable organizational phenomena, and how it is linked to the different organizational design actions to inform managerial action to create the SBMI capability effectively.

Last but not least, our work could be complemented with more investigation to open more research avenues. Sustainability involves high systemic complexity, it is hard to predict ex ante the outcome of most sustainability-oriented actions, and it is against the majority of existing businesses ecosystems. We need practical adoption of the idea, companies moving forward with potential solutions, trial and error, and many failures. Regardless, there is a need to compel practical adoption, and our proposition is in line with this idea.

Author Contributions: Conceptualisation, V.M., M.F. and I.S.R.; methodology, V.M., M.F., I.S.R. and M.H.; validation, V.M., M.F. and I.S.R.; formal analysis, V.M., M.F. and I.S.R.; investigation, V.M. and M.F.; resources, V.M.; data curation, V.M., and M.F.; writing—original draft preparation, V.M., M.F., I.S.R., M.H., D.G., H.P. and R.Q.; writing-review and editing, V.M., M.F., I.S.R., M.H., D.G., H.P. and R.Q.; supervision, V.M., H.P. and R.Q.; project administration, V.M. All authors have read and agreed to the published version of the manuscript.

Funding: This work was supported by the Proyecto VRIEA-PUCV 039.350/2021 to Vinicius Minatogawa. Authors also acknowledge funding provided by DI Interdisciplinaria Pontificia Universidad Católica de Valparaíso (PUCV). Valparaíso (PUCV), 039.414/2021.

Institutional Review Board Statement: Not applicable.

Informed Consent Statement: Not applicable.

Data Availability Statement: The raw data of the findings presented are available from the corresponding author Vinicius Minatogawa on request.

Conflicts of Interest: The authors declare no conflict of interest.

\section{Appendix A}

Table A1. SBMI firm-level antecedents, the supporting publications, the definition of the dimensions, and how deep the studies dealt with each dimension.

\begin{tabular}{|c|c|c|c|c|}
\hline \multirow[b]{2}{*}{ Dimension } & \multicolumn{2}{|c|}{ Firm-Level Antecedents } & \multicolumn{2}{|c|}{ Investigation Deepness of Supporting Publications } \\
\hline & Construct & Concept & Mentioned in the Study & Focus of the Research \\
\hline & $\begin{array}{l}\text { Strategic orientation } \\
\text { towards Sustainability }\end{array}$ & $\begin{array}{l}\text { Top management team's } \\
\text { orientation towards sustainability. } \\
\text { Encompasses startups construction } \\
\text { and the set of values and beliefs. } \\
\text { Influences the strategic direction of } \\
\text { the company and the propensity to } \\
\text { pursue SBMI. }\end{array}$ & & $\begin{array}{c}\text { Bocken and Geradts [9]; } \\
\text { Pearse and Peterlin [83], } \\
\text { Hu et al. [75] }\end{array}$ \\
\hline $\begin{array}{c}\text { Strategic-LevelOrganizational } \\
\text { Design }\end{array}$ & Long-term perspective & $\begin{array}{l}\text { Thinking about the long term, } \\
\text { which includes environmental and } \\
\text { social value. } \\
\text { Contrasts to the short-term } \\
\text { perspective, which focuses on } \\
\text { fulfilling shareholder's needs and } \\
\text { in financial gains. } \\
\text { Influences the balance between } \\
\text { innovation efforts for making } \\
\text { money and for } \\
\text { creating sustainability. }\end{array}$ & & Bocken and Geradts [9] \\
\hline
\end{tabular}


Table A1. Cont.

\begin{tabular}{|c|c|c|c|c|}
\hline & \multicolumn{2}{|c|}{ Firm-Level Antecedents } & \multicolumn{2}{|c|}{ Investigation Deepness of Supporting Publications } \\
\hline Dimension & Construct & Concept & Mentioned in the Study & Focus of the Research \\
\hline \multirow[t]{3}{*}{$\begin{array}{c}\text { Strategic-LevelOrganizational } \\
\text { Design }\end{array}$} & $\begin{array}{l}\text { Ambiguity and risk } \\
\text { acceptance }\end{array}$ & $\begin{array}{l}\text { The extent to which the company } \\
\text { accepts ambiguity and risk, and } \\
\text { mitigates tensions and potential } \\
\text { trade-offs. } \\
\text { Navigating through SBMI } \\
\text { demands exploratory goals, which } \\
\text { has a longer potential time for } \\
\text { financial returns. SBM are not } \\
\text { currently in the dominant } \\
\text { paradigm, hence, they show a need } \\
\text { to uncover substantially novel, } \\
\text { unprecedented BMs, which are } \\
\text { ambiguous and uncertain. } \\
\text { Influences the innovation portfolio } \\
\text { mixed with projects for the short, } \\
\text { medium and long term. }\end{array}$ & $\begin{array}{l}\text { Girortra and Netissiene [106]; } \\
\text { Long et al. [96] }\end{array}$ & $\begin{array}{l}\text { Bocken and Geradts [9]; } \\
\text { Bommel [102] }\end{array}$ \\
\hline & Strategizing & $\begin{array}{l}\text { - } \quad \text { Strategic action to secure the } \\
\text { successful inclusion of new SBM } \\
\text { into the market, by mitigating. } \\
\text { supply network bottlenecks and } \\
\text { influencing relevant stakeholders. } \\
\text { Influences success rate of } \\
\text { new projects. }\end{array}$ & Long et al. [96] & $\begin{array}{c}\text { Biloslavo et al. [10]; } \\
\text { Brennan and } \\
\text { Tennant [79]; Stubbs [90] }\end{array}$ \\
\hline & $\begin{array}{l}\text { Organizational } \\
\text { Structure }\end{array}$ & $\begin{array}{l}\text { - How the organization structures } \\
\text { itself physically for constant SBMI } \\
\text { pursuing. } \\
\text { Influences the systematic or } \\
\text { emerging character of SBMI efforts. }\end{array}$ & Bocken and Geradts [9] & Stubbs [90] \\
\hline \multirow{4}{*}{$\begin{array}{c}\text { Capability-levelDynamic } \\
\text { Capabilities }\end{array}$} & $\begin{array}{l}\text { Technological } \\
\text { Capabilities }\end{array}$ & $\begin{array}{l}\text { The company's overall } \\
\text { technological capabilities, both in } \\
\text { design and implementation of new } \\
\text { technologies. } \\
\text { It suffers influences from R\&D. } \\
\text { Influences the ability to coordinate } \\
\text { new SBMs with new } \\
\text { eco-innovations, and the ability to } \\
\text { recognize new technological } \\
\text { opportunities. }\end{array}$ & Hu et al. [75] & $\begin{array}{l}\text { Inigo et al., [14]; } \\
\text { Mukherjee and } \\
\text { Wood [86] }\end{array}$ \\
\hline & $\begin{array}{l}\text { Multiple BM } \\
\text { Management } \\
\text { capability }\end{array}$ & $\begin{array}{l}\text { Refers to integrational capability to } \\
\text { run both current BM and explore } \\
\text { new SBMs mitigating conflicts and } \\
\text { potentializing complementarities. } \\
\text { It is connected to ambidexterity, } \\
\text { complementarities, and } \\
\text { complementary assets' building, } \\
\text { and demands strategizing to } \\
\text { adequately align the multiple BM } \\
\text { and SBM. } \\
\text { Influences survival of the projects } \\
\text { inside and outside the company. } \\
\text { Cannibalization of current business } \\
\text { may retract people from interest in } \\
\text { new SBMs, for example. }\end{array}$ & $\begin{array}{c}\text { Bocken and Geradts [9]; } \\
\text { Hu et al. [75] }\end{array}$ & Inigo et al. [14] \\
\hline & $\begin{array}{c}\text { Balancing BM } \\
\text { portfolio management }\end{array}$ & $\begin{array}{l}\text { The capability of the company to } \\
\text { keep a mix of projects that keeps } \\
\text { organizational financially healthy } \\
\text { while exploring SBMs for } \\
\text { the future. } \\
\text { Influences the extent to which SBM } \\
\text { projects will pass, kill or keep } \\
\text { gatekeeps, and the extent to which } \\
\text { SBM projects will receive resources. }\end{array}$ & Bocken and Geradts [9] & \\
\hline & $\begin{array}{c}\text { Collaborative } \\
\text { innovation capability }\end{array}$ & $\begin{array}{l}\text { The company's capability to } \\
\text { integrate multiple stakeholders } \\
\text { into the innovation process. } \\
\text { Multiple-stakeholders' } \\
\text { involvement means bringing in for } \\
\text { cocreation and integrating external } \\
\text { competences necessary for the } \\
\text { new SBMs. }\end{array}$ & $\begin{array}{c}\text { Bocken and Geradts [9]; } \\
\text { Brennan and Tennant [79]; } \\
\text { Long et al. [96] }\end{array}$ & $\begin{array}{c}\text { Inigo et al. [14]; } \\
\text { Wadin et al. [93]; Stål } \\
\text { et al. [94] }\end{array}$ \\
\hline
\end{tabular}


Table A1. Cont.

\begin{tabular}{|c|c|c|c|c|}
\hline & \multicolumn{2}{|c|}{ Firm-Level Antecedents } & \multicolumn{2}{|c|}{ Investigation Deepness of Supporting Publications } \\
\hline Dimension & Construct & Concept & Mentioned in the Study & Focus of the Research \\
\hline \multirow{6}{*}{$\begin{array}{c}\text { Capability-levelDynamic } \\
\text { Capabilities }\end{array}$} & $\begin{array}{c}\text { Resources } \\
\text { mobilization and } \\
\text { orchestration }\end{array}$ & $\begin{array}{l}\text { How a company secures and } \\
\text { mobilizes resources for } \\
\text { SBM projects. } \\
\text { It involves financial, relational } \\
\text { (stakeholders' engagement), } \\
\text { human (teams) and organizational } \\
\text { (structure and buy-in). } \\
\text { Influences the long-term health of } \\
\text { SBMI efforts. }\end{array}$ & Hu et al. [75] & \\
\hline & $\begin{array}{c}\text { Teams and people } \\
\text { deployment capability }\end{array}$ & $\begin{array}{l}\text { Refers to the extent to which the } \\
\text { company builds the teams } \\
\text { responsible for SBMI projects. } \\
\text { It means identifying and training } \\
\text { adequate personnel (from inside } \\
\text { and form outside) the company. } \\
\text { Additionally, leverage the } \\
\text { combination of technological, } \\
\text { market and business } \\
\text { model knowledge. } \\
\text { Influences the teams' capabilities to } \\
\text { design, experiment (and learn) and } \\
\text { implement SBMI. }\end{array}$ & & $\begin{array}{c}\text { Weissbrod et al. [137]; } \\
\text { Peralta et al. [91]; } \\
\text { Inigo et al. [14]; } \\
\text { Wadin et al., [93] }\end{array}$ \\
\hline & $\begin{array}{l}\text { supply network } \\
\text { influencing } \\
\text { capabilities }\end{array}$ & $\begin{array}{l}\text { Refers to a companies capability to } \\
\text { influence supply network and } \\
\text { stakeholders' behavior towards } \\
\text { new SBM immersion into the } \\
\text { market/society. } \\
\text { SBM usually do not have an } \\
\text { adequate supply network, } \\
\text { customer behavior, or institutional } \\
\text { setting, which calls for legitimizing } \\
\text { and lobbying. } \\
\text { Influences the potential for the } \\
\text { SBMI to be successfully } \\
\text { implemented in practice. }\end{array}$ & Inigo et al. [14] & $\begin{array}{l}\text { Biloslavo et al. [10]; } \\
\text { Velter et al. [105]; } \\
\text { Hu et al. [75]; Brennan } \\
\text { and Tennant [79]; } \\
\text { Laukkanen M., } \\
\text { Patala S. [92]; } \\
\text { Stål et al. [94] }\end{array}$ \\
\hline & $\begin{array}{l}\text { Experimentation } \\
\text { capabilities }\end{array}$ & $\begin{array}{l}\text { Refers to the capability to craft } \\
\text { well-designed experiments that } \\
\text { deliver high-quality knowledge. } \\
\text { Using tools and experiments is not } \\
\text { sufficient to extract valuable } \\
\text { knowledge. Influences the quality } \\
\text { of the recognized opportunity and } \\
\text { the fit with the SBM }\end{array}$ & & Weissbrod et al. [137] \\
\hline & $\begin{array}{l}\text { Customer education } \\
\text { capability }\end{array}$ & $\begin{array}{l}\text { The capability to educate and } \\
\text { induce new behavior in customers } \\
\text { to stimulate buy in for new SBM. } \\
\text { Customers locked-in current } \\
\text { dominant BM may impede a new } \\
\text { SBM to gain strenght and penetrate } \\
\text { the market. }\end{array}$ & & $\begin{array}{c}\text { Bocken and Short [68]; } \\
\text { Sattari et al. [89] }\end{array}$ \\
\hline & $\begin{array}{l}\text { Change management } \\
\text { and competencies } \\
\text { building }\end{array}$ & $\begin{array}{l}\text { The capability to create } \\
\text { commitment for } \\
\text { embracing change. } \\
\text { It involves creating (and } \\
\text { destroying) existing } \\
\text { business capabilities. } \\
\text { - Influences transformation } \\
\text { capability }\end{array}$ & & $\begin{array}{l}\text { Inigo et al. [14]; } \\
\text { Long et al. [96] }\end{array}$ \\
\hline
\end{tabular}


Table A1. Cont.

\begin{tabular}{|c|c|c|c|c|}
\hline \multirow[b]{2}{*}{ Dimension } & \multicolumn{2}{|c|}{ Firm-Level Antecedents } & \multicolumn{2}{|c|}{ Investigation Deepness of Supporting Publications } \\
\hline & Construct & Concept & Mentioned in the Study & Focus of the Research \\
\hline \multirow{2}{*}{$\begin{array}{l}\text { Individual- } \\
\text { levelOrganizational } \\
\text { Culture }\end{array}$} & $\begin{array}{c}\text { Incentives for } \\
\text { sustainability-oriented } \\
\text { behavior }\end{array}$ & $\begin{array}{l}\text { How the company stimulates and } \\
\text { induces sustainability-oriented } \\
\text { behavior from people. } \\
\text { Searching for } \\
\text { sustainability-oriented } \\
\text { opportunities and keeping projects } \\
\text { alive depends on people's intent } \\
\text { and availability to do so, which the } \\
\text { company may enable or hinder. } \\
\text { Influences the capabilities to sense, } \\
\text { seize and transform SBMI. }\end{array}$ & & Bocken and Geradts [9] \\
\hline & $\begin{array}{l}\text { Sustainability-oriented } \\
\text { mindset }\end{array}$ & $\begin{array}{l}\text { Refers to the overall sentiment } \\
\text { regarding sustainability, and the } \\
\text { mindset of people and } \\
\text { managerial layers. } \\
\text { It may be related to the incentive's } \\
\text { schemes and the way of thinking } \\
\text { such as lean thinking. } \\
\text { It influences the strength of the } \\
\text { engagement towards searching } \\
\text { and exploring SBMI. }\end{array}$ & & Bocken and Geradts [9] \\
\hline
\end{tabular}

Table A2. SBMI process and design tools and the supporting publications.

\begin{tabular}{|c|c|c|}
\hline Tool, Method, Activities, and Practices & Description & Publications \\
\hline BMC-Business Model Canvas & $\begin{array}{l}\text { - } \quad \text { Generic and the most-used visual tool in } \\
\text { mainstream BMI. } \\
\text { Nine blocks attempt to summarize the value } \\
\text { proposition, the customer interface, the value } \\
\text { creation, the partner interface, and the cost and } \\
\text { revenue structure. } \\
\text { Used to diagnose BMs unsustainability } \\
\text { (opportunity recognition), design new SBM ideas } \\
\text { (early stages of seizing), and communicate a new } \\
\text { design (middle stages of seizing). }\end{array}$ & $\begin{array}{l}\text { Osterwalder and Pigneur [97] (creator); Calabrese } \\
\text { et al., } 2018 \text { [98]; Mendoza et al., 2019 [81] }\end{array}$ \\
\hline TLC-Tripple Layered Canvas & $\begin{array}{l}\text { - It is a tool designed due to the limited applicability } \\
\text { of the BMC, purposefully including environmental } \\
\text { and social layers to the existing economic layer. } \\
\text { It consists of } 27 \text { blocks, nine for each layer. } \\
\text { It is applied in the same SBMI process stages as of } \\
\text { the mainstream BMC. }\end{array}$ & $\begin{array}{l}\text { Joyce and Paquin [99] (creator); } \\
\text { López-Nicolás et al., } 2021 \text { [85] }\end{array}$ \\
\hline $\begin{array}{l}\text { EBME-The Ecology of Business Models } \\
\text { Experimentation }\end{array}$ & $\begin{array}{l}\text { - Process-supporting tool which assists with } \\
\text { systemic thinking about sustainability issues. } \\
\text { It is suitable for ideating and diagnosing } \\
\text { sustainability-oriented opportunities, deploying } \\
\text { associated practices to design and test these ideas, } \\
\text { and designing a new SBM. }\end{array}$ & Bocken et al., 2019 [100] (creator) \\
\hline HOQ-House of Quality & $\begin{array}{l}\text { An adaptation of the well-established total quality } \\
\text { management tool House of Quality to understand, } \\
\text { identify and prioritize sustainable } \\
\text { value propositions. }\end{array}$ & Burhan et al., 2021 [82] \\
\hline SBM Pilot Canvas & $\begin{array}{l}\text { It is a tool designed as a process-supporting tool } \\
\text { that aids in the validation stages to support the } \\
\text { sound design of new SBMs. } \\
\text { It targets the sensing, refining, and validating } \\
\text { sustainable opportunities and seizing stage of the } \\
\text { SBMI process. }\end{array}$ & Baldassare et al., 2020 [103] \\
\hline The $4 W^{\prime} s$ & $\begin{array}{l}\text { - A tool to diagnose existing BM unsustainability by } \\
\text { identifying decision making through } 4 W^{\prime} \text { (Who, } \\
\text { What, Where, When). } \\
\text { Applicable for opportunity recognition in early } \\
\text { sensing stages. }\end{array}$ & Girortra e Netessine, 2013 [106] (creator) \\
\hline
\end{tabular}


Table A2. Cont.

\begin{tabular}{|c|c|c|}
\hline Tool, Method, Activities, and Practices & Description & Publications \\
\hline SVM-Stakeholder Value Mapping & $\begin{array}{l}\text { Aims to overcome an existing gap in more } \\
\text { traditional BM tools that focus on a customer } \\
\text { segment's value proposition, including other } \\
\text { relevant stakeholders in the analysis, such as } \\
\text { society and environment. } \\
\text { Its strength is in identifying new opportunities and } \\
\text { assisting value proposition design. }\end{array}$ & $\begin{array}{l}\text { Bocken et al., } 2015 \text { [70] (creator); Geissdoerfer et al., } \\
2016 \text { [69] }\end{array}$ \\
\hline $\begin{array}{l}\text { BECE-Backcasting and Ecodesign for the } \\
\text { Circular Economy }\end{array}$ & $\begin{array}{l}\text { A tool that combines top-down strategic reasoning } \\
\text { (Backcasting) with bottom-up product ecodesign } \\
\text { to support designing circular business models. } \\
\text { It ranges from early opportunity recognition } \\
\text { (sensing) to designing a new BM leveraging } \\
\text { ecodesign to support value offering (seizing) until } \\
\text { creating a strategy for implementing it (late stages } \\
\text { of seizing, initial transforming). }\end{array}$ & $\begin{array}{l}\text { Heyes et al., } 2018 \text { [80]; } \\
\text { Mendoza et al., } 2019 \text { [81] }\end{array}$ \\
\hline
\end{tabular}

Ecodesign

Circular Business Framework

Value Uncaptured

Paradoxical thinking

Ethnography
- Closely linked to creating a specific product to support a value proposition (early stages of seizing).

- A framework guide in a stepwise manner to assis in diagnosing and designing new circular business models (environmental-oriented).

- It is suitable for refining opportunity recognition (interfaces between sensing and seizing) until the early stages of SBM design.
Bocken et al., 2015 [70]; Heyes et al., 2018 [80]

Lauten-Weiss, 2021 [104]

- A method designed to diagnose current stage, aiding the identification of sustainable opportunities through value-uncaptured dimension.

- Its primary application is on opportunity recognition.
Yang et al., 2017 [107] (creator) Burhan et al., 2021 [82]

- It is a method used in combination with other tools to potentialize creative behavior for idea generation.

- $\quad$ Suitable for the creative stages of sensing and seizing, assisting the refinement of opportunities as on SBM design.

- An activity to assist in overcoming the dominant logic that sustainability entices trade-offs between economic, environmental, and social dimensions.

- It is applicable throughout identifying an opportunity, dealing with resistance to understand as opportunities, until designing an SBM, helping overcome dominant economy-first thinking.

- It targets legitimizing and strategizing for moving SBM design into application.

- It is applicable in the late seizing stages, where SBMs need further and more significant investments, buy in from the company, and strategic action to increase the likelihood of success.

- Attempts to improve success ratio and likelihood

- $\quad$ Focuses on final seizing stages, after an SBM is designed, to begin its practical implementation.

- It is a method for taking a deep dive into specific stakeholders, gaining internal and in-depth knowledge to support decision-making and creative behavior during the SBMI

- It is primarily applied in sensing and seizing stages. 
Table A2. Cont.

\begin{tabular}{|c|c|c|}
\hline Tool, Method, Activities, and Practices & Description & Publications \\
\hline Analogical Reasoning & $\begin{array}{l}\text { - A creativity-supporting practice that leverages } \\
\text { cross-industry and cross-company knowledge to } \\
\text { import ideas from one context to another (i.e., } \\
\text { using Rolls Royce pay-by-the-hour engine model } \\
\text { to commercialize, for example, refrigerators as } \\
\text { a service). } \\
\text { Applicable in creative stages of sensing and } \\
\text { seizing; to identify opportunities and to design } \\
\text { an SBM. }\end{array}$ & Yip and Bocken, 2018 [41]; Naor et al. (2019) [101] \\
\hline A/B testing & $\begin{array}{l}\text { It is a practice that supports testing and validating } \\
\text { specific parts or assumptions in a designed SBM. } \\
\text { Applicable in validation stages of sensing } \\
\text { and seizing. }\end{array}$ & Bocken et al., 2019 [100] \\
\hline Talking, Thinking, and Testing & $\begin{array}{l}\text { - It is an activity that targets supporting the } \\
\text { identification of an opportunity (talking), } \\
\text { designing an SBM through creativity supporting } \\
\text { alternatives (thinking), and validating the SBMs } \\
\text { elements and coherence (testing). }\end{array}$ & Baldassare et al., 2017 [78] (creator) \\
\hline Vision, strategic alignment, and prioritization & $\begin{array}{l}\text { Promotes a link between SBMI efforts and the } \\
\text { company's overall strategy through assisting in the } \\
\text { SBMI portfolio management. } \\
\text { It connects to prioritizing sustainable opportunities } \\
\text { to explore, selecting which ones to finance, and } \\
\text { moving forward in the innovation pipeline. }\end{array}$ & Heyes et al., 2018 [80]; Mendoza et al., 2019 [81] \\
\hline $\begin{array}{c}\text { Complementarities, conflicts, and supply } \\
\text { network evaluation }\end{array}$ & $\begin{array}{l}\text { Activity oriented towards managing multiple SBM } \\
\text { and optimizing new SBM likelihood of } \\
\text { legitimization and success. } \\
\text { It involves seizing, through evaluating new SBM } \\
\text { complementarities (e.g., grow tomatoes in addition } \\
\text { to refining sugar) and mitigating conflicts } \\
\text { (transforming a product into a service, hinders } \\
\text { scale economy and obsolescence of } \\
\text { previous business). } \\
\text { It applies to (1) existing previous BM; and (2) key } \\
\text { supply network stakeholders (create } \\
\text { complementary assets, influence behavior, etc.). }\end{array}$ & Short et al., 2014 [76]; Naor et al. (2019) [101] \\
\hline Boundary management & $\begin{array}{l}\text { - Especially looks for collaborative innovation and } \\
\text { aggregating multiple stakeholders into new SBM } \\
\text { buy in. } \\
\text { Targets sensing opportunities (boundary } \\
\text { dissonance), strategically aggregating } \\
\text { stakeholders, and mitigating conflicts (boundary } \\
\text { brokering) to seize opportunities, and, finally, } \\
\text { implementation through change management } \\
\text { (boundary implementation) for transforming. }\end{array}$ & Velter et al., 2020 [105] (creator) \\
\hline SOSI Tool & $\begin{array}{l}\text { - It is a tool to aid holistic thinking for identifying } \\
\text { sustainable-oriented opportunities, designing an } \\
\text { SBM through using the BMC combined with } \\
\text { SBM thinking. } \\
\text { Suitable to support sensing opportunities and } \\
\text { designing an SBM to seize such opportunities. }\end{array}$ & Calabrese et al., 2018 [98] (creator) \\
\hline
\end{tabular}

\section{References}

1. Edgecliffe-Johnson, A.; Mundy, S. Big Business and COP26: Are the 'Net Zero' Plans Credible? Financial Times. Available online: https:/ / www.ft.com/content/d91b5934-de9e-4eef-a008-697bce53263f (accessed on 2 December 2021).

2. Bowcott, H.; Pacthod, D.; Pinner, D. What COP26 Means for Business. McKinsey. Available online: https://www.mckinsey.com. br/business-functions/sustainability / our-insights/cop26-made-net-zero-a-core-principle-for-business-heres-how-leaderscan-act (accessed on 2 December 2021).

3. Handley, L. The Road to Cop26. CNBC. Available online: https://www.cnbc.com/2021/11/02/larry-fink-fears-for-energytransition-warns-of-market-arbitrage.html (accessed on 2 December 2021).

4. Conlon, S. 'Brands Have been Getting Away with Murder': Stella McCartney and Leading Fashion Figures on the Fallout of Cop26; Fashion. The Guardian. Available online: https://www.theguardian.com/fashion/2021/nov/26/brands-have-beengetting-away-with-stella-mccartney-and-leading-fashion-figures-on-the-fallout-of-cop26 (accessed on 2 December 2021).

5. Lüdeke-Freund, F.; Carroux, S.; Joyce, A.; Massa, L.; Breuer, H. The sustainable business model pattern taxonomy-45 patterns to support sustainability-oriented business model innovation. Sustain. Prod. Consum. 2018, 15, 145-162. [CrossRef] 
6. O'Brien, R. Surf's up! Chile Start-Up Turns Fishing Nets into Skateboards. Reuters. Available online: https://www.reuters.com/ article/chile-business-skateboards-idUKL6N0TO4KC20141211 (accessed on 2 December 2021).

7. Stappmanns, F. Sustainable Business Model Innovation: The Cases of Patagonia Inc. and Bureo Skateboards. Inimpact J. Innov. Impact 2016, 8, 349.

8. Davies, I.A.; Chambers, L. Integrating hybridity and business model theory in sustainable entrepreneurship. J. Clean. Prod. 2018, 177, 378-386. [CrossRef]

9. Bocken, N.M.P.; Geradts, T.H.J. Barriers and drivers to sustainable business model innovation: Organization design and dynamic capabilities. Long Range Plann. 2020, 53. [CrossRef]

10. Biloslavo, R.; Bagnoli, C.; Massaro, M.; Cosentino, A. Business model transformation toward sustainability: The impact of legitimation. Manag. Decis. 2020, 58, 1643-1662. [CrossRef]

11. Bocken, N.M.P.; Short, S.W. Unsustainable business models-Recognising and resolving institutionalised social and environmental harm. J. Clean. Prod. 2021, 312, 127828. [CrossRef]

12. Teece, D.J. Explicating Dynamic Capabilities: The nature and microfoundations of (sustainable) enterprise performance. Strateg. Manag. J. 2007, 27, 1319-1350. [CrossRef]

13. Teece, D.J. Business models and dynamic capabilities. Long Range Plann. 2018, 51, 40-49. [CrossRef]

14. Inigo, E.A.; Albareda, L.; Ritala, P. Business model innovation for sustainability: Exploring evolutionary and radical approaches through dynamic capabilities. Ind. Innov. 2017, 24, 515-542. [CrossRef]

15. Franco, M.; Minatogawa, V.; Duran, O.; Batocchio, A.; Quadros, R. Opening the Dynamic Capability Black Box: An Approach to Business Model Innovation Management in the Digital Era. IEEE Access 2021, 9, 69189-69209. [CrossRef]

16. Randhawa, K.; Wilden, R.; Gudergan, S. How to innovate toward an ambidextrous business model? The role of dynamic capabilities and market orientation. J. Bus. Res. 2021, 130, 618-634. [CrossRef]

17. Zollo, M.; Winter, S.G. Deliberate learning and the evolution of dynamic capabilities. Organ. Sci. 2002, 13. [CrossRef]

18. Nielsen, A.P. Understanding dynamic capabilities through knowledge management. J. Knowl. Manag. 2006, 10, 59-71. [CrossRef]

19. Geissdoerfer, M.; Vladimirova, D.; Evans, S. Sustainable business model innovation: A review. J. Clean. Prod. 2018, 198, 401-416. [CrossRef]

20. Shakeel, J.; Mardani, A.; Chofreh, A.G.; Goni, F.A.; Klemeš, J.J. Anatomy of sustainable business model innovation. J. Clean. Prod. 2020, 261, 121201. [CrossRef]

21. Pieroni, M.P.P.; McAloone, T.C.; Pigosso, D.C.A. Business model innovation for circular economy and sustainability: A review of approaches. J. Clean. Prod. 2019, 215, 198-216. [CrossRef]

22. Täuscher, K.; Abdelkafi, N. Visual tools for business model innovation: Recommendations from a cognitive perspective. Creat. Innov. Manag. 2017, 26, 160-174. [CrossRef]

23. Schwarz, J.S.; Legner, C. Business model tools at the boundary: Exploring communities of practice and knowledge boundaries in business model innovation. Electron. Mark. 2020, 30, 421-445. [CrossRef]

24. Wirtz, B.; Daiser, P. Business Model Innovation Processes: A Systematic Literature Review. J. Bus. Model. 2018, 6, 40-58. [CrossRef]

25. Laudien, S.M.; Daxböck, B. Business model innovation processes of average market players: A qualitative-empirical analysis. $R D$ Manag. 2017, 47, 420-430. [CrossRef]

26. Batie, S. Fellows Address: Wicked Problems and Applied Economics on JSTOR. Am. J. Agric. Econ. 2008, 90, 1176-1191. [CrossRef]

27. Bucherer, E.; Eisert, U.; Gassmann, O. Towards Systematic Business Model Innovation: Lessons from Product Innovation Management. Creat. Innov. Manag. 2012, 21, 183-198. [CrossRef]

28. Savitz, A.W.; Weber, K. The Triple Bottom Line: How Today's Best-Run Companies Are Achieving Economic, Social, and Environmental Success-and How You Can Too; Jossey-Bass: San Francisco, CA, USA, 2006; 320p.

29. Japutra, A.; Ekinci, Y.; Simkin, L. Self-congruence, brand attachment and compulsive buying. J. Bus. Res. 2019, 99, 456-463. [CrossRef]

30. Meza-Ruiz, I.D.; Rocha-Lona, L.; del Rocío Soto-Flores, M.; Garza-Reyes, J.A.; Kumar, V.; Lopez-Torres, G.C. Measuring Business Sustainability Maturity-levels and Best Practices. Procedia Manuf. 2017, 11, 751-759. [CrossRef]

31. Hart, S.L.; Milstein, M.B. Creating sustainable value. Acad. Manag. Perspect. 2003, 17, 56-69. [CrossRef]

32. Keeble, B.R. World Commission on Environment and Development Report of the World Commission on Environment and Development: Our Common Future (The Brundtland Report). Med. Confl. Surviv. 1987, 4. [CrossRef]

33. Van der Byl, C.A.; Slawinski, N. Embracing Tensions in Corporate Sustainability: A Review of Research from Win-Wins and Trade-Offs to Paradoxes and Beyond. Organ. Environ. 2015, 28, 54-79. [CrossRef]

34. Calabrese, A.; Costa, R.; Levialdi, N.; Menichini, T. Integrating sustainability into strategic decision-making: A fuzzy AHP method for the selection of relevant sustainability issues. Technol. Forecast. Soc. Change 2019, 139, 155-168. [CrossRef]

35. Finke, T.; Gilchrist, A.; Mouzas, S. Why companies fail to respond to climate change: Collective inaction as an outcome of barriers to interaction. Ind. Mark. Manag. 2016, 58, 94-101. [CrossRef]

36. Veleva, V.; Bodkin, G. Corporate-entrepreneur collaborations to advance a circular economy. J. Clean. Prod. 2018, 188, 20-37. [CrossRef]

37. Molina-Castillo, F.J.; Sinkovics, N.; Sinkovics, R.R. Sustainable Business Model Innovation: Review, Analysis and Impact on Society. Sustainability 2021, 13, 8906. [CrossRef] 
38. Natura Valorizar a Sabedoria da Floresta-Amazônia Importa-Natura. Estúdio Folha. Available online: https:/ / estudio.folha.uol. com.br/amazonia-importa-natura/2020/08/1988814-valorizar-a-sabedoria-da-floresta.shtml (accessed on 2 December 2021).

39. Evans, S.; Vladimirova, D.; Holgado, M.; Van Fossen, K.; Yang, M.; Silva, E.A.; Barlow, C.Y. Business Model Innovation for Sustainability: Towards a Unified Perspective for Creation of Sustainable Business Models. Bus. Strateg. Environ. 2017, 26, 597-608. [CrossRef]

40. Bocken, N.M.P.; Short, S.W.; Rana, P.; Evans, S. A literature and practice review to develop sustainable business model archetypes. J. Clean. Prod. 2014, 65, 42-56. [CrossRef]

41. Yip, A.W.H.; Bocken, N.M.P. Sustainable business model archetypes for the banking industry. J. Clean. Prod. 2018, 174, 150-169. [CrossRef]

42. Foss, N.J.; Saebi, T. Fifteen Years of Research on Business Model Innovation: How Far Have We Come, and Where Should We Go? J. Manag. 2016, 43, 200-227. [CrossRef]

43. Nosratabadi, S.; Mosavi, A.; Shamshirband, S.; Zavadskas, E.K.; Rakotonirainy, A.; Chau, K.W. Sustainable Business Models: A Review. Sustainability 2019, 11, 1663. [CrossRef]

44. Goni, F.A.; Chofreh, A.G.; Orakani, Z.E.; Klemeš, J.J.; Davoudi, M.; Mardani, A. Sustainable business model: A review and framework development. Clean Technol. Environ. Policy 2020, 23, 889-897. [CrossRef]

45. Barth, H.; Ulvenblad, P.-O.; Ulvenblad, P. Towards a Conceptual Framework of Sustainable Business Model Innovation in the Agri-Food Sector: A Systematic Literature Review. Sustainability 2017, 9, 1620. [CrossRef]

46. Sinkovics, N.; Gunaratne, D.; Sinkovics, R.R.; Molina-Castillo, F.-J. Sustainable Business Model Innovation: An Umbrella Review. Sustainability 2021, 13, 7266. [CrossRef]

47. Magretta, J. Why Business models matter. Harv. Bus. Rev. 2002, 80, 86-92.

48. Christensen, C.M.; Bartman, T.; van Bever, D. The Hard Truth about Business Model Innovation. Sloan Manag. Rev. 2016, 58, 31-40.

49. Lindgren, P. Business Model Innovation Leadership: How Do SME's Strategically Lead Business Model Innovation? Int. J. Bus. Manag. 2012, 7, 53. [CrossRef]

50. Sosna, M.; Trevinyo-Rodríguez, R.N.; Velamuri, S.R. Business model innovation through trial-and-error learning: The naturhouse case. Long Range Plann. 2010, 43, 383-407. [CrossRef]

51. Minatogawa, V.; Franco, M.; Durán, O.; Quadros, R.; Holgado, M.; Batocchio, A. Carving out New Business Models in a Small Company through Contextual Ambidexterity: The Case of a Sustainable Company. Sustainability 2020, 12, 2337. [CrossRef]

52. Albats, E.; Podmetina, D.; Vanhaverbeke, W. Open innovation in SMEs: A process view towards business model innovation. J. Small Bus. Manag. 2021. [CrossRef]

53. Chesbrough, H. The Future of Open Innovation. Res. Technol. Manag. 2017, 60, 35-38. [CrossRef]

54. Fjeldstad, Ø.D.; Snow, C.C. Business models and organization design. Long Range Plann. 2018, 51, 32-39. [CrossRef]

55. Gopalakrishnan, K.; Chitturi, M.V.; Prentkovskis, O. Smart and sustainable transport: Short review of the special issue. Vilnius Gedim. Tech. Univ. 2015, 30, 243-246. [CrossRef]

56. Kajikawa, Y.; Ohno, J.; Takeda, Y.; Matsushima, K.; Komiyama, H. Creating an academic landscape of sustainability science: An analysis of the citation network. Sustain. Sci. 2007, 2, 221-231. [CrossRef]

57. Secundo, G.; Rippa, P.; Cerchione, R. Digital Academic Entrepreneurship: A structured literature review and avenue for a research agenda. Technol. Forecast. Soc. Change 2020, 157. [CrossRef]

58. Feng, Y.; Zhu, Q.; Lai, K.H. Corporate social responsibility for supply chain management: A literature review and bibliometric analysis. J. Clean. Prod. 2017, 158, 296-307. [CrossRef]

59. van Eck, N.J.; Waltman, L. VOSviewer Manual Version 1.6.16. Univeristeit Leiden. 2020, pp. 1-52. Available online: https: / / www.vosviewer.com/documentation/Manual_VOSviewer_1.6.16.pdf (accessed on 15 September 2021).

60. Denyer, D.; Tranfield, D. Producing a systematic review. In The Sage Handbook of Organizational Research Methods; Buchanan, D.A., Bryman, A., Eds.; SAGE Publications Ltd.: Thousand Oaks, CA, USA, 2009; pp. 671-689.

61. Xavier, A.F.; Naveiro, R.M.; Aoussat, A.; Reyes, T. Systematic literature review of eco-innovation models: Opportunities and recommendations for future research. J. Clean. Prod. 2017, 149, 1278-1302. [CrossRef]

62. Martins, V.W.B.; Rampasso, I.S.; Anholon, R.; Quelhas, O.L.G.; Leal Filho, W. Knowledge management in the context of sustainability: Literature review and opportunities for future research. J. Clean. Prod. 2019, 229, 489-500. [CrossRef]

63. Moher, D.; Liberati, A.; Tetzlaff, J.; Altman, D.G.; Group, T.P. Preferred reporting items for systematic reviews and meta-analyses: The PRISMA statement. Int. J. Surg. 2010, 8, 336-341. [CrossRef]

64. Elo, S.; Kyngäs, H. The qualitative content analysis process. J. Adv. Nurs. 2008, 62, 107-115. [CrossRef]

65. Chesbrough, H. Business Model Innovation: Opportunities and Barriers. Long Range Plann. 2010, 43, 354-363. [CrossRef]

66. Lüdeke-Freund, F.; Dembek, K. Sustainable business model research and practice: Emerging field or passing fancy? J. Clean. Prod. 2017, 168, 1668-1678. [CrossRef]

67. Sousa-Zomer, T.T.; Cauchick-Miguel, P.A. Exploring business model innovation for sustainability: An investigation of two product-service systems. Total Qual. Manag. Bus. Excell. 2019, 30. [CrossRef]

68. Bocken, N.M.P.; Short, S.W. Towards a sufficiency-driven business model: Experiences and opportunities. Environ. Innov. Soc. Transit. 2016, 18, 41-61. [CrossRef] 
69. Geissdoerfer, M.; Bocken, N.; Hultink, E.J. Design thinking to enhance the sustainable business modelling process-A workshop based on a value mapping process. J. Clean. Prod. 2016, 135, 1218-1232. [CrossRef]

70. Bocken, N.M.P.; Rana, P.; Short, S.W. Value mapping for sustainable business thinking. J. Ind. Prod. Eng. 2015, 32, 67-81. [CrossRef]

71. Johnson, M.W.; Christensen, C.M.; Kagermann, H. Reinventing your business model. Harv. Bus. Rev. 2008, 86, 50-59.

72. Chesbrough, H. Business model innovation: It's not just about technology anymore. Strategy Leadersh. 2007, 35, 12-17. [CrossRef]

73. Yunus, M.; Moingeon, B.; Lehmann-Ortega, L. Building social business models: Lessons from the grameen experience. Long Range Plann. 2010, 43, 308-325. [CrossRef]

74. Tiscini, R.; Testarmata, S.; Ciaburri, M.; Ferrari, E. The blockchain as a sustainable business model innovation. Manag. Decis. 2020, 58, 1621-1642. [CrossRef]

75. Hu, H.; Huang, T.; Cheng, Y.; Lu, H. The Evolution of Sustainable Business Model Innovation: Evidence from a Sharing Economy Platform in China. Sustainability 2019, 11, 4207. [CrossRef]

76. Short, S.W.; Bocken, N.M.P.; Barlow, C.Y.; Chertow, M.R. From Refining Sugar to Growing Tomatoes. J. Ind. Ecol. 2014, 18, 603-618. [CrossRef]

77. Franceschelli, M.V.; Santoro, G.; Candelo, E. Business model innovation for sustainability: A food start-up case study. Br. Food J. 2018, 120, 2483-2494. [CrossRef]

78. Baldassarre, B.; Calabretta, G.; Bocken, N.; Jaskiewicz, T. Bridging sustainable business model innovation and user-driven innovation: A process for sustainable value proposition design. J. Clean. Prod. 2017, 147, 175-186. [CrossRef]

79. Brennan, G.; Tennant, M. Sustainable value and trade-offs: Exploring situational logics and power relations in a UK brewery's malt supply network business model. Bus. Strategy Environ. 2018, 27, 621-630. [CrossRef]

80. Heyes, G.; Sharmina, M.; Mendoza, J.M.F.; Gallego-Schmid, A.; Azapagic, A. Developing and implementing circular economy business models in service-oriented technology companies. J. Clean. Prod. 2018, 177, 621-632. [CrossRef]

81. Mendoza, J.M.F.; Gallego-Schmid, A.; Azapagic, A. Building a business case for implementation of a circular economy in higher education institutions. J. Clean. Prod. 2019, 220, 553-567. [CrossRef]

82. Burhan; Ciptomulyono, U.; Singgih, M.L.; Baihaqi, I. Sustainable Business Model Innovations in the Value Uncaptured Manufacturing Industry: Fitting Gains-Gain Creators. Sustainability 2021, 13, 5647. [CrossRef]

83. Pearse, N.J.; Peterlin, J. Artistic creative social entrepreneurs and business model innovation. J. Res. Mark. Entrep. 2019, 21, 149-162. [CrossRef]

84. He, J.; Ortiz, J. Sustainable business modeling: The need for innovative design thinking. J. Clean. Prod. 2021, 298, 126751. [CrossRef]

85. López-Nicolás, C.; Ruiz-Nicolás, J.; Mateo-Ortuño, E. Towards Sustainable Innovative Business Models. Sustainability 2021, 13, 5804. [CrossRef]

86. Mukherjee, M.; Wood, J. Consolidating Unorganised Retail Businesses through Digital Platforms: Implications for Achieving the UN Sustainable Development Goals. Sustainability 2021, 13, 12031. [CrossRef]

87. Stubbs, W.; Cocklin, C. Conceptualizing a "Sustainability Business Model. " Organ. Environ. 2008, 21, 103-127. [CrossRef]

88. Ulvenblad, P.; Ulvenblad, P.; Tell, J. An overview of sustainable business models for innovation in Swedish agri-food production. J. Integr. Environ. Sci. 2019, 16,1-22. [CrossRef]

89. Sattari, S.; Wessman, A.; Borders, L. Business model innovation for sustainability: An investigation of consumers' willingness to adopt product-service systems. J. Glob. Sch. Mark. Sci. 2020, 30, 274-290. [CrossRef]

90. Stubbs, W. Strategies, practices, and tensions in managing business model innovation for sustainability: The case of an Australian BCorp. Corp. Soc. Responsib. Environ. Manag. 2019, 26. [CrossRef]

91. Peralta, A.; Carrillo-Hermosilla, J.; Crecente, F. Sustainable business model innovation and acceptance of its practices among Spanish entrepreneurs. Corp. Soc. Responsib. Environ. Manag. 2019, 26, 1119-1134. [CrossRef]

92. Laukkanen, M.; Patala, S. Analysing Barriers to Sustainable Business Model Innovations: Innovation Systems Approach. Int. J. Innov. Manag. 2014, 18, 1440010. [CrossRef]

93. Wadin, J.L.; Ahlgren, K.; Bengtsson, L. Joint business model innovation for sustainable transformation of industries-A large multinational utility in alliance with a small solar energy company. J. Clean. Prod. 2017, 160, 139-150. [CrossRef]

94. Stål, H.I.; Bengtsson, M.; Manzhynski, S. Cross-sectoral collaboration in business model innovation for sustainable development: Tensions and compromises. Bus. Strateg. Environ. 2021. [CrossRef]

95. Todeschini, B.V.; Cortimiglia, M.N.; Callegaro-de-Menezes, D.; Ghezzi, A. Innovative and sustainable business models in the fashion industry: Entrepreneurial drivers, opportunities, and challenges. Bus. Horiz. 2017, 60, 759-770. [CrossRef]

96. Long, T.B.; Looijen, A.; Blok, V. Critical success factors for the transition to business models for sustainability in the food and beverage industry in the Netherlands. J. Clean. Prod. 2018, 175, 82-95. [CrossRef]

97. Osterwalder, A.; Pigneur, Y. Business Model Generation; John Wiley \& Sons: Hoboken, NJ, USA, 2010.

98. Calabrese, A.; Forte, G.; Ghiron, N.L. Fostering sustainability-oriented service innovation (SOSI) through business model renewal: The SOSI tool. J. Clean. Prod. 2018, 201. [CrossRef]

99. Joyce, A.; Paquin, R.L. The triple layered business model canvas: A tool to design more sustainable business models. J. Clean. Prod. 2016, 135, 1474-1486. [CrossRef]

100. Bocken, N.; Boons, F.; Baldassarre, B. Sustainable business model experimentation by understanding ecologies of business models. J. Clean. Prod. 2019, 208, 1498-1512. [CrossRef] 
101. Naor, M.; Druehl, C.; Bernardes, E.S. Servitized business model innovation for sustainable transportation: Case study of failure to bridge the design-implementation gap. J. Clean. Prod. 2018, 170, 1219-1230. [CrossRef]

102. van Bommel, K. Managing tensions in sustainable business models: Exploring instrumental and integrative strategies. J. Clean. Prod. 2018, 196. [CrossRef]

103. Baldassarre, B.; Konietzko, J.; Brown, P.; Calabretta, G.; Bocken, N.; Karpen, I.O.; Hultink, E.J. Addressing the designimplementation gap of sustainable business models by prototyping: A tool for planning and executing small-scale pilots. J. Clean. Prod. 2020, 255, 120295. [CrossRef]

104. Lauten-Weiss, J.; Ramesohl, S. The Circular Business Framework for Building, Developing and Steering Businesses in the Circular Economy. Sustainability 2021, 13, 963. [CrossRef]

105. Velter, M.G.E.; Bitzer, V.; Bocken, N.M.P.; Kemp, R. Sustainable business model innovation: The role of boundary work for multi-stakeholder alignment. J. Clean. Prod. 2020, 247, 119497. [CrossRef]

106. Girotra, K.; Netessine, S. OM forum: Business model innovation for Sustainability. Manuf. Serv. Oper. Manag. 2013, 15, 537-544. [CrossRef]

107. Yang, M.; Evans, S.; Vladimirova, D.; Rana, P. Value uncaptured perspective for sustainable business model innovation. J. Clean. Prod. 2017, 140, 1794-1804. [CrossRef]

108. Brown, P.; Bocken, N.; Balkenende, R. How Do Companies Collaborate for Circular Oriented Innovation? Sustainability 2020, 12, 1648. [CrossRef]

109. Angeli, F.; Jaiswal, A.K. Business Model Innovation for Inclusive Health Care Delivery at the Bottom of the Pyramid. Organ. Environ. 2016, 29, 486-507. [CrossRef]

110. Winterhalter, S.; Zeschky, M.B.; Neumann, L.; Gassmann, O. Business Models for Frugal Innovation in Emerging Markets: The Case of the Medical Device and Laboratory Equipment Industry. Technovation 2017, 66-67, 3-13. [CrossRef]

111. Leemann, N.; Kanbach, D.K. Toward a taxonomy of dynamic capabilities-a systematic literature review. Manag. Res. Rev. 2021. [CrossRef]

112. Buzzao, G.; Rizzi, F. On the conceptualization and measurement of dynamic capabilities for sustainability: Building theory through a systematic literature review. Bus. Strategy Environ. 2021, 30, 135-175. [CrossRef]

113. Frankenberger, K.; Weiblen, T.; Csik, M.; Gassmann, O. The $4 \mathrm{I}$-framework of business model innovation: A structured view on process phases and challenges. Int. J. Prod. Dev. 2013, 18, 249-273. [CrossRef]

114. Trimi, S.; Berbegal-Mirabent, J. Business model innovation in entrepreneurship. Int. Entrep. Manag. J. 2012, 8, 449-465. [CrossRef]

115. Tidd, J.; Bessant, J. Innovation Management Challenges: From Fads to Fundamentals. Int. J. Innov. Manag. 2018, 22. [CrossRef]

116. Slotegraaf, R.J. Keep the Door Open: Innovating Toward a More Sustainable Future. J. Prod. Innov. Manag. 2012, $29,349-351$. [CrossRef]

117. Carayannis, E.G.; Grigoroudis, E.; Stamati, D.; Valvi, T. Social Business Model Innovation: A Quadruple/Quintuple Helix-Based Social Innovation Ecosystem. IEEE Trans. Eng. Manag. 2021, 68, 235-248. [CrossRef]

118. Asswad, J.; Hake, G.; Gómez, J.M. Overcoming the Barriers of Sustainable Business Model Innovations by Integrating Open Innovation. Lect. Notes Bus. Inf. Process. 2016, 255, 302-314. [CrossRef]

119. Boons, F.; Lüdeke-Freund, F. Business models for sustainable innovation: State-of-the-art and steps towards a research agenda. J. Clean. Prod. 2013, 45, 9-19. [CrossRef]

120. Brown, P.; Baldassarre, B.; Konietzko, J.; Bocken, N.; Balkenende, R. A tool for collaborative circular proposition design. J. Clean. Prod. 2021, 297, 126354. [CrossRef]

121. Du, S.; Bstieler, L.; Yalcinkaya, G. Sustainability-focused innovation in the business-to-business context: Antecedents and managerial implications. J. Bus. Res. 2022, 138, 117-129. [CrossRef]

122. Troise, C.; Tani, M.; Dinsmore, J.; Schiuma, G. Understanding the implications of equity crowdfunding on sustainability-oriented innovation and changes in agri-food systems: Insights into an open innovation approach. Technol. Forecast. Soc. Change 2021, 171, 120959. [CrossRef]

123. Chistov, V.; Aramburu, N.; Carrillo-Hermosilla, J. Open eco-innovation: A bibliometric review of emerging research. J. Clean. Prod. 2021, 311, 127627. [CrossRef]

124. Markides, C.C. Business Model Innovation: What Can the Ambidexterity Literature Teach US? Acad. Manag. Perspect. 2013, 27, 313-323. [CrossRef]

125. Ogilvie, T. How to Thrive in the Era of Collaborative Services Entrepreneurship. Res. Manag. 2015, 58, 24-34. [CrossRef]

126. Teece, D.J.; Peteraf, M.; Leih, S. Dynamic Capabilities and Organizational Agility: Risk, uncertainty, and strategy in the innovation economy. Calif. Manag. Rev. 2016, 58, 13-35. [CrossRef]

127. Ernkvist, M. The double knot of technology and business-model innovation in the era of ferment of digital exchanges: The case of OM, a pioneer in electronic options exchanges. Technol. Forecast. Soc. Change 2015, 99, 285-299. [CrossRef]

128. Bock, A.J.; Opsahl, T.; George, G.; Gann, D.M. The Effects of Culture and Structure on Strategic Flexibility during Business Model Innovation. J. Manag. Stud. 2012, 49, 279-305. [CrossRef]

129. Loon, M.; Otaye-Ebede, L.; Stewart, J. Thriving in the New Normal: The HR Microfoundations of Capabilities for Business Model Innovation. An Integrated Literature Review. J. Manag. Stud. 2020, 57, 698-726. [CrossRef]

130. Malik, A.; Pereira, V.; Tarba, S. The role of HRM practices in product development: Contextual ambidexterity in a US MNC's subsidiary in India. Int. J. Hum. Resour. Manag. 2019, 30, 536-564. [CrossRef] 
131. Chesbrough, $\mathrm{H}$. The role of the business model in capturing value from innovation: Evidence from Xerox Corporation's technology spin-off companies. Ind. Corp. Chang. 2002, 11, 529-555. [CrossRef]

132. Bashir, M.; Verma, R. Airbnb disruptive business model innovation: Assessing the impact on hotel industry. Int. J. Arts-Based Educ. Res. 2016, 14, 2595-2604.

133. Giesen, E.; Riddleberger, E.; Christner, R.; Bell, R. When and how to innovate your business model. Strateg. Amp; Leadersh. 2010, 38, 17-26. [CrossRef]

134. Anagnostopoulos, I. Fintech and regtech: Impact on regulators and banks. J. Econ. Bus. 2018, 100, 7-25. [CrossRef]

135. Christensen, C.M. The Innovator's Dilemma, 2nd ed.; Harper Business: New York, NY, USA, 2000; ISBN 0-06-662069-4.

136. Schumpeter, J.A. Capitalism, Socialism and Democracy. In Modern Economic Classics-Evaluations through Time; Taylor and Francis: Abingdon, UK, 2017; pp. 242-269. ISBN 9781351982399.

137. Weissbrod, I.; Bocken, N. Developing sustainable business experimentation capability: A case study. J. Clean. Prod. 2017, 142, 2663-2676. [CrossRef] 